\title{
Effects of macroalgal accumulations on the variability in zoobenthos of high-energy macrotidal sandy beaches
}

\author{
Nolwenn Quillien ${ }^{1,2,3, *}$, Marie C. Nordström ${ }^{2}$, Olivier Gauthier ${ }^{1,3}$, Erik Bonsdorff ${ }^{2}$, \\ Yves-Marie Paulet ${ }^{1,3}$, Jacques Grall ${ }^{3}$
}

${ }^{1}$ Laboratoire des Sciences de l'Environnement Marin, UMR 6539, Institut Universitaire Européen de la Mer, Plouzané, France

${ }^{2}$ Åbo Akademi University, Department of Biosciences, Environmental and Marine Biology, Turku, Finland

${ }^{3}$ Observatoire des Sciences de la mer et de l'univers, UMS 3113, Institut Universitaire Européen de la Mer, Plouzané, France

\begin{abstract}
Sandy beaches, forming the most widespread coastal habitat in the world, are threatened by the effects of increasing anthropogenic pressure in the context of global change, including the increased occurrence of green tides composed of free-living Ulva spp. Sandy beaches are also highly dynamic ecosystems that support numerous essential ecological functions and contain a distinctive biodiversity, but their precise functioning and natural variability (i.e. the disentangling of biological and physical influences) remain under-studied. Our study aimed at determining the effects of space, time, and environmental variables on the natural variability of macrofaunal community structure and at specifically determining the effects of macroalgal accumulations on the observed variability. We followed a high-resolution field sampling design in space and time (261 samples) at non-vegetated and at partially and fully green-tide-impacted macrotidal sandy beaches. We used novel statistical approaches (distance-based Moran's eigenvector maps [dbMEMs] and variation partitioning) to analyse our results. The macrofaunal community structure of the non-vegetated sandy beach was variable in space and time at small scales, and physical environmental variables significantly explained these variations. Our study also highlighted a decrease in this variability along a gradient of increasing coverage of stranded Ulva spp. and the increasing importance of biological variables in explaining ecological variability. Compared to a state with no Ulva, a large and homogeneous coverage of Ulva along a sandy beach shore induced a significant decrease of overall $\beta$-diversity. However, macrofaunal responses to macroalgal accumulation were less pronounced than what has been previously shown in micro-tidal and sheltered systems, likely due to the dynamic and unstable nature of high-energy macrotidal sandy shores.
\end{abstract}

KEY WORDS: Macrotidal sandy beach $\cdot$ Macrofauna $\cdot$ Green tides $\cdot$ Space-time analysis $\cdot \beta$-diversity Resale or republication not permitted without written consent of the publisher

\section{INTRODUCTION}

Sandy beach (SB) ecosystems harbour many organisms that are all specialized and adapted to life in mobile sediments. At regional to global scales, SBs contribute highly to $\beta$-diversity and support numerous essential ecological functions such as filtering large amounts of water, mineralizing organic matter, and recycling nutrients, as well as forming nurseries and feeding areas for commercially important fishes (Schlacher et al. 2008). Beach ecosystems make up two-thirds of the world's ice-free coastline (McLachlan \& Brown 2006) and provide both resources and recreational opportunities. More than half of the world's human population lives within $60 \mathrm{~km}$ of the shoreline (Turner et al. 1996). Hence, SBs are threatened by increasing direct and indirect anthropogenic pressures, such as fishing, coastal development and 

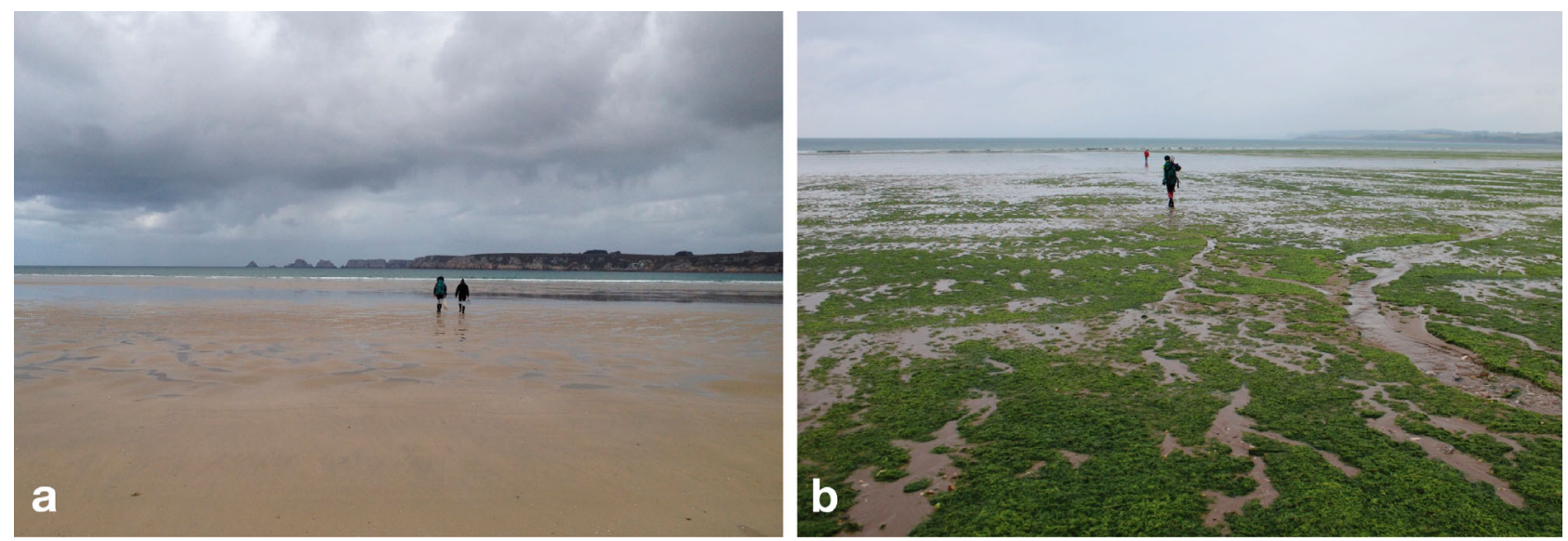

Fig. 1. Illustration of green tides in the Bay of Douarnenez, Brittany, France: (a) Sandy beach (SB) that never harbours green tides; (b) SB that harbours green tides during spring and summer. Photo credits: E. Bonsdorff (a) and N. Quillien (b)

pollution (Schlacher et al. 2007, Defeo et al. 2009). One of the most important human-induced pressures is excess nutrient release into water bodies and the resulting eutrophication (Cloern 2001).

One of the direct symptoms of nutrient enrichment in coastal areas is the rapid and important development of assemblages of macroalgae with short lifecycles (Cloern 2001). Such notable blooms are increasing in frequency and intensity worldwide (Ye et al. 2011). In the northeastern Atlantic Ocean, beaches of Brittany (Western France) are particularly affected by stranded Ulva spp. (hereafter Ulva or green macroalgae) mats (Ménesguen \& Piriou 1995, Charlier et al. 2007; Fig. 1); 51 open macrotidal (mean spring tide $>4 \mathrm{~m}$, Allaby 2010) sandy beaches and 33 mud flats hosted green tides in 2013 (CGDD 2014). The presence of such free-living macroalgal mats affects exchange between sediments and water and modifies local hydrodynamics (Hull 1987, Jeffrey et al. 1992), primary production (Sundbäck 1994, Bombelli \& Lenzi 1996), and benthic fauna (Hull 1987, Norkko \& Bonsdorff 1996). Most of the studies that have been conducted on this issue were carried out in very sheltered environments (i.e. mud flats; see Raffaelli et al. 1998, Ouisse et al. 2011), have involved semi-controlled experiments in the field (Norkko \& Bonsdorff 1996, Thiel \& Watling 1998), and have mostly addressed the question in nonor micro-tidal systems (Norkko \& Bonsdorff 1996, Thiel \& Watling 1998). The tidal regime is an additional factor to the variability of coastal marine systems, and much still remains to be discovered and explained regarding the ecological effects of algal accumulations in open macrotidal sandy beach systems.
In their review addressing the threats facing sandy shore ecosystems, Brown \& McLachlan (2002) showed that the question of the effects of organic enrichment through eutrophication in sandy shore ecosystems has been mostly studied in sheltered lagoons and in estuaries. The effects of macroalgal mats on open sandy beach systems have mainly been addressed by experimental studies based on controlled algal manipulations, which implies important limitations when trying to understand ecosystemscale response to such perturbation (Bolam et al. 2000, Franz \& Friedman 2002). Thus, to our knowledge, except for meiofaunal communities (Carriço et al. 2013), there is no published research that has studied the effects of green tides on swash zone communities living in highly dynamic sandy systems such as open macrotidal beaches.

Since the 1980s, the understanding of the ecology of sandy shores has greatly advanced (Defeo \& McLachlan 2005, McLachlan \& Brown 2006, Nel et al. 2014). Numerous studies have described acrossshore distribution of benthic macrofauna (e.g. Schlacher \& Thompson 2013), and, today, alongshore distribution of specific sandy beach populations is well known (e.g. Lercari \& Defeo 1999, Defeo \& de Alava 1995, Schoeman \& Richardson 2002). In microtidal sandy systems, James \& Fairweather (1996) have shown that SB macrobenthic community structure varies along-shore. However, such work has not been conducted in macrotidal systems. Thus, several spatial community patterns and their drivers are still to be fully understood. Regarding temporal variation, seasonal trends have been recorded in macrofaunal assemblages living in intertidal softbottom systems (Leber 1982, Degraer et al. 1999, Da 
Silva et al. 2008). Yet those studies have been mostly species-specific or used low-frequency sampling designs (ca. 6 mo between samplings), while Addicott et al. (1987) and Botsford et al. (1997) stress that ecological research often requires detailed and finescaled knowledge to understand patterns and processes. In addition, ecological processes may be better studied by simultaneous consideration of both spatial and temporal variation (Resh \& Rosenberg 1989). Studies that consider both time and space in soft-sediment community ecology remain scarce (Hewitt et al. 2001, Ysebaert \& Herman 2002). Regarding sandy beaches, the use of such an approach is still emerging (Veloso \& Cardoso 2001, Carcedo et al. 2014).

The limited number of studies assessing how the combination of several factors structures benthic macrofaunal assemblages may be explained by the complexity of analysing multivariate data accounting for effects of time, space, and other environmental variables simultaneously. This issue is an important topic in community ecology (Rundle \& Jackson 1996, Anderson \& Gribble 1998, Ysebaert \& Herman 2002). Hence, biostatisticians and numerical ecologists have developed methods incorporating resampling and permutational functions to answer ecological questions using multivariate and multiscale spatial and temporal data sets (Dray et al. 2012). The present study is one of the first using such an approach to disentangle the effects of time, space, and environmen- tal factors, including green tides, on sandy swashzone benthic communities.

The aim of the present study was thus to explain the variation of benthic infauna of macrotidal (mean spring-tide $>4 \mathrm{~m}$ ) sandy beaches. This was done by studying the following hypotheses: variation in macrofaunal benthic structure is dependent on (1) location at small spatial scale (hundreds of meters) along the swash-zone, (2) time/month (season) of the year, and (3) presence of Ulva spp. macroalgal blooms. In other words, we examined whether changes in the community were identifiable by analysing the effects of temporal, spatial, and environmental variables, specifically eutrophication in the form of biomass of Ulva spp., on the benthic assemblages over an annual cycle.

\section{MATERIALS AND METHODS}

\section{Study area}

The study was performed in the bay of Douarnenez (Brittany, France), where sediments accumulate to form kilometre-scale sandy beaches (Fig. 2). Three beaches were selected for this study: one that does not harbour green tides $\left(\mathrm{SB}_{\mathrm{A}}\right)$ (Fig. 1a), one that harbours spatially heterogeneous green tides $\left(\mathrm{SB}_{\mathrm{B}}\right)$, and a third one $\left(\mathrm{SB}_{\mathrm{C}}\right)$ that receives green tides homogeneously along the entire shore (Fig. 1b). Thus, the 3 a

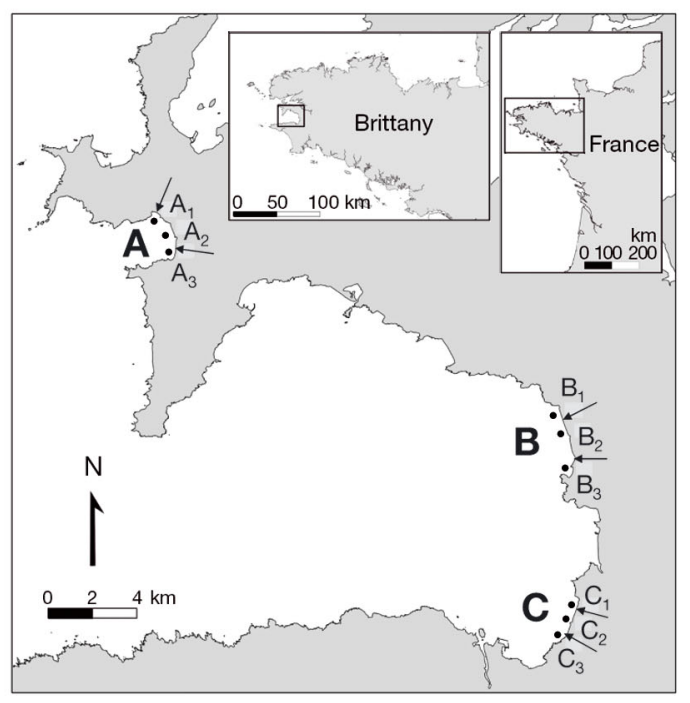

b

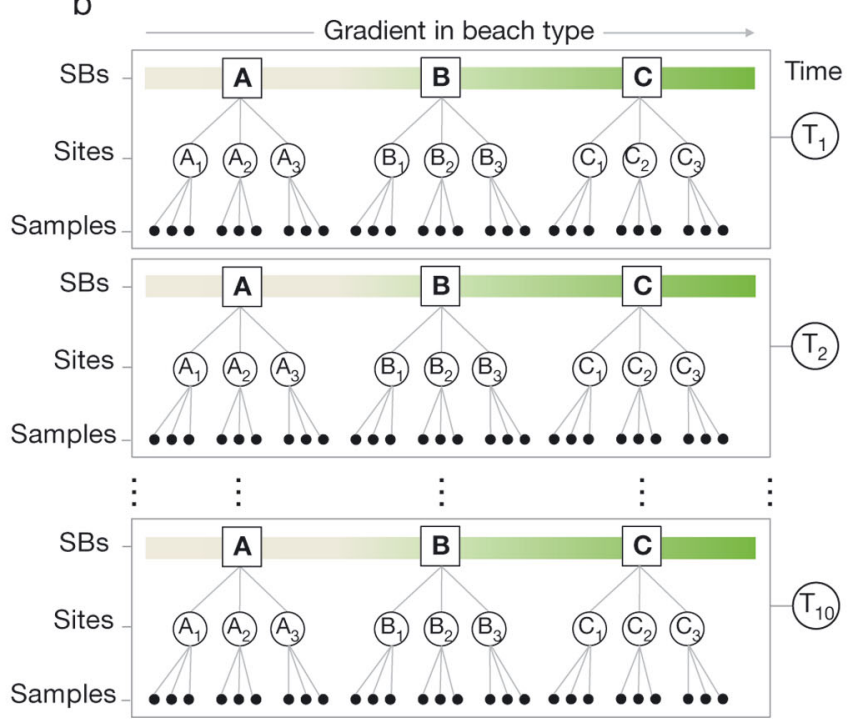

Fig. 2. (a) Location (Brittany, France) of the 3 sandy beaches (SBs: A, B and C), the 9 sampling sites (black filled circles) where 3 replicates were sampled monthly and the coastal rivers' mouths (arrows). (b) Sampling design, repeated in time (10 dates: $\left.T_{1}, T_{2}, \ldots T_{10}\right)$ showing the $3 \mathrm{SBs}(\mathrm{A}, \mathrm{B}$ and $\mathrm{C})$, the corresponding sampling sites $\left(\mathrm{A}_{1}, \mathrm{~A}_{2}, \mathrm{~A}_{3}, \mathrm{~B}_{1}, \mathrm{~B}_{2}, \mathrm{~B}_{3}, \mathrm{C}_{1}, \mathrm{C}_{2}, \mathrm{C}_{3}\right)$ and the samples (black circles) 
SBs form a gradient of beach types (Fig. 2b). We make use of this gradient, and since the performed analyses (see 'Data analyses') are based upon linear regression, they do not require replication of each value along the independent variable (here, the beach type, Fig. 2b). The $3 \mathrm{SBs}$, open to the west, show large areas (up to $500 \mathrm{~m}$ from shore during spring tides) that are uncovered at low tide (mean tidal regime $=6.5 \pm 0.5 \mathrm{~m}$ ). They are characterized by a lower shore with a slope of $1.5 \%$, and since the tidal regime is macrotidal, these SBs are defined as dissipative beaches (Short 1996, Hénaff 1998). The length of the beaches ranges from 2.1 to $3.0 \mathrm{~km}$. The anthropogenic impacts on $\mathrm{SB}_{\mathrm{A}}$ are negligible. Indeed, the continental water inputs are filtered by a wetland area just behind the beach, and the urbanization there is limited. In contrast, $\mathrm{SB}_{\mathrm{B}}$ and $\mathrm{SB}_{\mathrm{C}}$ are located below agricultural catchment areas and have experienced yearly Ulva bloom events since the early 1980s (Ménesguen \& Piriou 1995, Charlier et al. 2007).

\section{Field sampling}

To assess macrofaunal variability along the shore, sampling was conducted at 3 sampling sites distributed latitudinally at the same level along the swash zone (spring low tide) at the north, middle, and south of the $3 \mathrm{SBs}\left(\mathrm{A}_{1}=48^{\circ} 15.206^{\prime} \mathrm{N}, 4^{\circ} 33.298^{\prime} \mathrm{W}_{;} \mathrm{A}_{2}=\right.$ $48^{\circ} 15.003^{\prime} \mathrm{N}, 4^{\circ} 33.051^{\prime} \mathrm{W} ; \mathrm{A}_{3}=48^{\circ} 14.109^{\prime} \mathrm{N}, 4^{\circ}$ $32.545^{\prime} \mathrm{W}^{\prime} \mathrm{B}_{1}=48^{\circ} 11.355^{\prime} \mathrm{N}, 4^{\circ} 18.202^{\prime} \mathrm{W}^{\prime} \mathrm{B}_{2}=48^{\circ}$ $11.193^{\prime} \mathrm{N}, 4^{\circ} 18.149^{\prime} \mathrm{W}_{i} \mathrm{~B}_{3}=48^{\circ} 10.132^{\prime} \mathrm{N}, 4^{\circ} 17.465^{\prime} \mathrm{W}_{\text {; }}$ $\mathrm{C}_{1}=48^{\circ} 06.585^{\prime} \mathrm{N}, 4^{\circ} 17.050^{\prime} \mathrm{W} ; \mathrm{C}_{2}=48^{\circ} 06.367^{\prime} \mathrm{N}$, $4^{\circ} 17.145^{\prime} \mathrm{W}^{\prime} \mathrm{C}_{3}=48^{\circ} 06.105^{\prime} \mathrm{N}, 4^{\circ} 17.263^{\prime} \mathrm{W}$ ) (Fig. 2). The distance between each adjacent 2 of the 3 sampling sites within a beach ranged from 700 to $1300 \mathrm{~m}$ (mean of $900 \pm 200 \mathrm{~m}$ ). To evaluate temporal variability of benthic communities within each of the stations, all sites were sampled monthly from April 2012 to February 2013 (except in December 2012 for $\mathrm{SB}_{\mathrm{C}}$ and in January 2013 for all sites due to unfavourable meteorological conditions) within a day for each beach.

Macrofauna (>1 mm) was collected using a tubecorer (inner diameter: $11.3 \mathrm{~cm}$; depth: $15 \mathrm{~cm}$ ). To obtain faunal samples covering an area of $300 \mathrm{~cm}^{2}$, 3 cores (circa $40 \mathrm{~cm}$ apart) were pooled to obtain 1 sample (Fig. 2b). These pooled core samples were sieved through mesh bags ( $1 \mathrm{~mm}$ mesh size) to separate the fauna from the sediment. At each sampling site $\left(A_{1}, A_{2}\right.$, etc. $), 3$ such replicate samples were randomly taken 1 to $2 \mathrm{~m}$ apart. Faunal samples were preserved in $4 \%$ buffered formalin for later sorting in the lab where macrofauna were identified to the low- est possible taxonomic level with the aid of a binocular magnifier, counted, and weighed. Species nomenclature follows the 'World Register of Marine Species' (www.marinespecies.org/). Biomass of each taxon was measured by weight loss after combustion at $450^{\circ} \mathrm{C}$ for $4 \mathrm{~h}$ (ash-free dry weight).

Species richness was the number of species per sample. Abundance and biomass were converted to units per $\mathrm{m}^{2}$. In addition to the quantitative data set, global information on biological traits was linked to each dominant species. Information about the feeding ecology, mobility, size, and reproduction for the dominant species was thus gathered from peerreviewed literature and publicly available databases such as MarLIN/BIOTIC and EOL/polytraits (sensu Törnroos \& Bonsdorff 2012).

At each site where fauna was sampled (Fig. 2a, $\left.A_{1,2,3 ;} \quad B_{1,2,3 ;} \quad C_{1,2,3}\right)$, a single sediment core was extracted (in the same way as fauna cores) to obtain grain size and organic matter content characteristics. Grain sizes were measured by dry-sieving, using a series of 16 sieves from 63 to $10000 \mu \mathrm{m}$. The sorting index (SI) was calculated based on the first and third quartile ratio (VQ25/Q75, where Q25 and Q75 denote the first and the third quartiles of the sediment grain size, respectively), and the median (Q50) was equal to the second quartile of the sediment grain size value (hereafter referred to as 'median'). Organic matter content was measured by weight loss after combustion at $450^{\circ} \mathrm{C}$ for $5 \mathrm{~h}$. Beach slope was calculated for each sampling site by geometry (maximal tide/shore width). Ulva biomass was estimated by CEVA (www.ceva.fr/fre) through monthly aerial surveys (for estimation of surface area covered by mats) and field sampling (for conversion into biomass). Since CEVA's data were included in a GIS (geographic information system) database, Ulva biomass was calculated for 3 at each beach (each polygon was one third of the beach surface and contained 1 sampling site, e.g. site A1, see Fig. 2a) along shore in order to integrate spatial-heterogeneity along SBs.

Seawater temperature, salinity, and dissolved oxygen content were measured on each sampling occasion using a YSI-OMS v2 probe. Monthly mean values for phytoplankton concentrations and for wave height were taken from the publicly available database PREVIMER (www.previmer.org/observations). PREVIMER estimates plankton concentration using the ECO-MARS-3D model (grid $=4 \mathrm{~km}$ ), and the wave height was calculated using the model WW3 (grid $=200 \mathrm{~m}$ ). Wind speed was assessed by averaging the values for wind velocity of $5 \mathrm{~d}$ before each sampling date using data of the Pointe du Raz 
meteorological station (www.infoclimat.fr/observations-meteo/temps-reel/pointe-du-raz/07103.html). The environmental parameters measured at beach scale (seawater temperature, salinity, dissolved oxygen content, plankton concentration, wave height, and wind velocity) were considered homogeneous within each beach (e.g. salinity at $\mathrm{SB}_{\mathrm{A}}=$ salinity at Sites $\mathrm{A}_{1}, \mathrm{~A}_{2}$, and $\mathrm{A}_{3}$ ).

\section{Data analyses}

Effect of site on species richness throughout the SBs was assessed with sample-based rarefaction curves for the 9 sampling sites (from $A_{1}$ to $C_{3}$ ). Expected species richness was plotted as a function of the expected number of individuals to allow meaningful comparisons (Gotelli \& Colwell 2001) among sites. Macrofauna diversity was assessed using the following primary community variables and diversity indices (Gray \& Elliott 2009): abundance (A), biomass $(B)$, species richness $(S)$, and numerical equivalents of Shannon's entropy $\left(\exp \left(H^{\prime}\right)\right)$ and Simpson's $(1 / D)$ indices following the method of Jost (2006) for unified interpretation of diversity. The temporal (monthly sampling from April 2012 to February 2013) and spatial (along the beach) variation in each of these univariate variables was assessed to extricate diversity trends.

Before performing statistical tests on these univariate characteristics of macrofaunal $\alpha$-diversity, all faunal and environmental variables were checked for normality (graphically and using Agostino test) and fourth-root, log, or arcsine transformed if necessary. Environmental characteristics between beaches and/or sampling occasions were tested to determine if and how the 3 SBs experienced different environmental conditions. For slope, estimated once from bathymetric maps for each of the 9 sites (see 'Field sampling'), a Kruskal-Wallis test was used. For variables measured repeatedly through time at a single site per beach (seawater temperature, salinity, dissolved oxygen, and wave height), Friedman tests were used to test for consistent differences among beaches over time. Finally, after checking for homogeneity of variance, 2-way ANOVAs with permutations were used for variables measured with replication in both space and time (Ulva biomass, sorting index, organic matter, and median). Furthermore, to disentangle the effects of time, environment, and space on the univariate variables $\left(A, B, S, H^{\prime}\right.$, and $\left.D\right)$, 2 recently developed methods were combined: distance-based Moran's eigenvector maps (dbMEMs;
Dray et al. 2006, Legendre \& Gauthier 2014) were used in variation partitioning (Borcard \& Legendre 1994). First, dbMEM eigenfunctions were generated based on the number of sampling occasions and the number of days between sampling occasions. The generated dbMEM eigenfunctions were used as temporal variables (here called MEMs, see Fig. S1 in the Supplement at www.int-res.com/articles/suppl/ m522p097_supp.pdf). MEMs can model both positive and negative temporal patterns, and both models were assessed. Forward selection (Blanchet et al. 2008) was then used to select significant MEMs. The location along the shore was used as a spatial variable and was coded by Helmert contrasts (Legendre \& Anderson 1999). Variation in the univariate responses was then partitioned with respect to 3 groups of explanatory variables: environment (the 10 variables describing physical and biological environment of each site after normalization), space (the location along the shore), and time (the selected MEMs). Each fraction of variation, i.e. the explanatory power of each set of the explanatory variables, was tested by multiple and partial (for pure explanatory power, see Fig. S2 in the Supplement, blue section) linear regression (Legendre \& Legendre 2012). The importance of each environmental factor (i.e. the 10 variables describing physical and biological environment of each site) in explaining univariate responses was assessed using stepwise selection in multiple regression.

To test the null hypothesis of no differences among benthic assemblages through time between the 3 beaches, a multivariate analysis of variance (MANOVA) with permutation tests was computed by redundancy analysis (RDA) based on Hellingertransformed abundance matrices of the 3 SBs (Legendre \& Legendre 2012, Legendre \& Gauthier 2014). For all multidimensional analyses, faunal data were first transformed using the Hellinger transformation, which is recommended for analysing abundance and biomass of species data since it does not give high weights to rare species (Legendre \& Gallagher 2001). The 2 factors, beach and time, and their interaction, were coded by Helmert contrasts (Legendre \& Anderson 1999). Homogeneity of multivariate dispersion was tested prior to this analysis. Principal component analyses (PCAs) were performed to visualize patterns in the distribution of assemblages of macrofauna in space and time within each SB. The total $\beta$-diversity (BDTotal) is defined as the total variance of a community matrix (sensu Legendre \& De Càceres 2013). BDTotal was computed for each of the 3 sites within each sandy beach 
$\left(\mathrm{SB}_{\mathrm{A}}, \mathrm{SB}_{\mathrm{B}}\right.$, and $\left.\mathrm{SB}_{\mathrm{C}}\right)$ for each sampling occasion (only 8 sampling events - April to November 2012, i.e. 72 data points - were included to ensure a balanced design in this analysis). To assess if macroalgal accumulations are associated with general losses of $\beta$ diversity, BDTotal values were correlated (Kendall rank correlation) with the sum of Ulva coverage at each beach. To test if the different regimes of macroalgal accumulations could be linked to overall $\beta$ diversity, differences in BDTotal between beaches were assessed using 3 pairwise Wilcoxon-MannWhitney tests followed by a Holm probability correction for multiple testing.

Finally, redundancy analysis (RDA) was used to replace the 3 beaches in the overall context and determine how environmental, spatial, and temporal variables constrain the variation of benthic communities in this setting. MEM variables were used to model time, and forward selection was applied as in the previous analyses. To maintain balanced sampling effort in space and time, data from December 2012 were not used in analyses performed on all 3 beaches together. Finally, to circumvent the missed survey of January 2013 and consider data series with regular sampling intervals $(1 \mathrm{mo})$, data from February 2013 were removed from all time-series modelling.

All analyses were conducted within the R environment (R Development Core Team 2013) and relied on the BiodiversityR (Kindt \& Coe 2005), vegan (Oksanen et al. 2011), PCNM (Legendre et al. 2013), and packfor (Dray et al. 2013) packages.

\section{RESULTS}

\section{Environmental characterization}

Environmental characteristics for the period April 2012 to February 2013 of $\mathrm{SB}_{\mathrm{A}}, \mathrm{SB}_{\mathrm{B}}$, and $\mathrm{SB}_{\mathrm{C}}$ are presented in Table 1. Seawater temperature, salinity, and dissolved oxygen content showed no significant differences among the 3 SBs. The environment is fully marine and well oxygenized. Likewise, wave height, beach slope, and chl a concentration were not significantly different among the 3 beaches. A significant effect of beach $\left(\mathrm{SB}_{\mathrm{A}, \mathrm{B}, \mathrm{C}}\right)$ was found for the sorting index and median grain size, the latter also varying significantly in time. Finally, a significant interaction of the 2 factors 'beach' and 'time' explained variations of organic matter content and Ulva biomass. Significant statistical interaction implies that the effect of a factor (e.g. time) is not constant across the levels of another (e.g. beach).

No Ulva was reported from $\mathrm{SB}_{\mathrm{A}}$, while the mean biomass of fresh green macroalgae mats was estimated at approximately 720 and $340 \mathrm{t}$ stranded along $\mathrm{SB}_{\mathrm{B}}$ and $\mathrm{SB}_{\mathrm{C}}$, respectively. Particularly large standard deviations were found for Ulva biomass (Table 1) due to the temporal variability of stranded macroalgae, which annually occurs in spring and summer. Considering the 3 sampling sites along the shore of $\mathrm{SB}_{\mathrm{B}}$ and $\mathrm{SB}_{\mathrm{C}}$, Ulva biomass washed ashore was variable both in time (Fig. 3a,c) and space (Fig. 3b,d). Macroalgae biomass measured on $\mathrm{SB}_{\mathrm{B}}$ showed a gradient from Site $B_{1}$ to Site $B_{3}$ with a maximum in June,

Table 1. Environmental characterization of the 3 beaches $\left(\mathrm{SB}_{\mathrm{A}}, \mathrm{SB}_{\mathrm{B}}\right.$, and $\left.\mathrm{SB}_{\mathrm{C}}\right)$ sampled monthly from April 2012 to February 2013 and the associated tests for the effects of beach (Be), time (Ti), and their interaction (Be $\times$ Ti) on environmental variables sampled monthly alongshore (Ulva biomass, SI, organic matter content, median), monthly at the beach scale (SWT, salinity, dissolved oxygen, wave height, chl a), and on a single occasion for the 3 sites along-shore (slope). The table presents the significant effects ( $\mathrm{p}$ 0.05); a dash denotes no significant effect. 2w-A: 2-way ANOVA with permutations; F: Friedman test; KW: Kruskal-Wallis. SWT: seawater temperature; median: Q50 (second quartile of the sediment grain size); SI: sorting index calculated based on first and third quartile ratio ( $\sqrt{ } \mathrm{Q} 25 / \mathrm{Q} 75$, where Q25 and Q75 denote the first and the third quartiles of the sediment grain size, respectively); P: physicochemical variable; B: biological variable

\begin{tabular}{|c|c|c|c|c|c|c|c|c|c|c|}
\hline \multirow[t]{2}{*}{ Variable } & \multirow[t]{2}{*}{ Tyрe } & \multicolumn{2}{|c|}{$\mathrm{SB}_{\mathrm{A}}$} & \multicolumn{2}{|c|}{$\mathrm{SB}_{\mathrm{B}}$} & \multicolumn{2}{|c|}{$\mathrm{SB}_{\mathrm{C}}$} & \multirow[t]{2}{*}{ Sources } & \multirow[t]{2}{*}{ Test } & \multirow[t]{2}{*}{ Effect } \\
\hline & & Mean & SD & Mean & SD & Mean & SD & & & \\
\hline Ulva biomass $\left(10^{3} \mathrm{~kg}\right)$ & B & 0.00 & 0.00 & 722.99 & 401.47 & 340.21 & 101.9 & CEVA & $2 \mathrm{w}-\mathrm{A}$ & $\mathrm{Be} \times \mathrm{Ti}$ \\
\hline Sorting index & $\mathrm{P}$ & 1.24 & 0.10 & 1.13 & 0.06 & 1.21 & 0.09 & Present study & $2 \mathrm{w}-\mathrm{A}$ & $\mathrm{Be}$ \\
\hline Organic matter (\%) & B & 4.45 & 0.47 & 4.11 & 0.74 & 4.14 & 0.48 & Present study & $2 \mathrm{w}-\mathrm{A}$ & $\mathrm{Be} \times \mathrm{Ti}$ \\
\hline Median & $\mathrm{P}$ & 180.37 & 25.07 & 158.52 & 11.99 & 176.87 & 22.06 & Present study & $2 \mathrm{w}-\mathrm{A}$ & $\mathrm{Be}, \mathrm{Ti}$ \\
\hline $\operatorname{SWT}\left({ }^{\circ} \mathrm{C}\right)$ & $\mathrm{P}$ & 14.58 & 3.39 & 14.68 & 4.39 & 15.44 & 2.82 & Present study & $\mathrm{F}$ & - \\
\hline Salinity & $\mathrm{P}$ & 34.9 & 0.59 & 34.86 & 0.41 & 34.9 & 0.42 & Present study & $\mathrm{F}$ & - \\
\hline Dissolved oxygen (\%) & $\mathrm{P} / \mathrm{B}$ & 103.38 & 2.23 & 103.91 & 2.62 & 104.05 & 4.13 & Present study & $\mathrm{F}$ & - \\
\hline Wave height (m) & $\mathrm{P}$ & 1.35 & 0.43 & 1.42 & 0.49 & 1.59 & 0.66 & Raz Observatory & $\mathrm{F}$ & - \\
\hline Chl a $\left(\mu \mathrm{g} \mathrm{l^{-1 }}\right)$ & B & 15.79 & 9.86 & 15.79 & 9.86 & 15.79 & 9.68 & PREVIMER & - & - \\
\hline Slope (\%) & $\mathrm{P}$ & 0.02 & 0.00 & 0.01 & 0.00 & 0.02 & 0.00 & Present study & K-W & - \\
\hline
\end{tabular}


while $\mathrm{SB}_{\mathrm{C}}$ showed no clear gradient pattern. There, stranding was homogeneous throughout the beach (Fig. 3d).

\section{Spatial-temporal variation in diversity patterns}

Over the 10 mo of the study and among the 261 samples, a total of 12781 macrofauna individuals were identified belonging to 67 different species. Crustacea was the most represented phylum within the community, with 29 malacostraca species, followed by Annelida with 26 polychaete species and Mollusca with 6 species. Other species belonged to Nemertea, Echinodermata, Sipuncula, Platyhelminthes, and Cnidaria. Considering each sampling site and a given number of individuals ( $\mathrm{n}=720$, i.e. the lowest total number for any site), species accumulation curves (Fig. 4) give the highest estimated species richness for Sites $\mathrm{B}_{1}$ and $\mathrm{B}_{2}(S=32$ and 33 respectively). Sites $A_{1}, A_{2}, A_{3}$, and $B_{3}$ exhibited similar values $(26,27,28$, and 28, respectively). Species richness estimated for sites sampled on $\mathrm{SB}_{\mathrm{C}}$ were the lowest, with values ranging from 21 to 24 .

The different primary community variables $(A, B, S$, $H^{\prime}$, and $D$ ) displayed temporal patterns and did not follow the same arrays (Fig. 5; for additional information regarding spatial variation along-shore, see also Fig. S3 in the Supplement) within the SBs (A, B, and C). The development of fauna (abundance and bio-

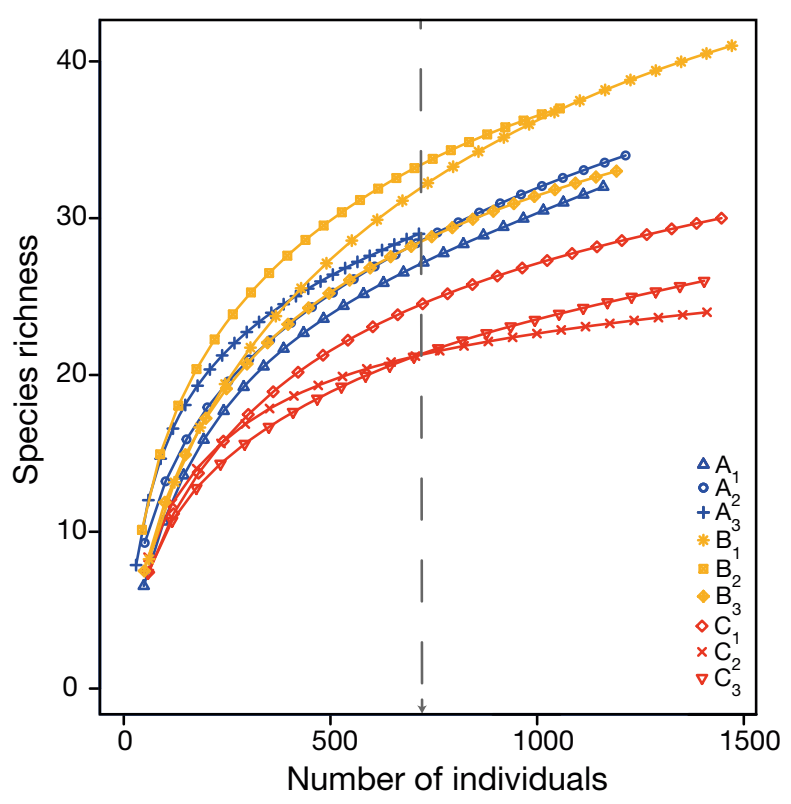

Fig. 4. Sample-based rarefaction curves for the 3 SBs (A, B and $C$ ) and each site. The dashed grey vertical arrow indicates the chosen number of individuals for comparison between sites $(n=720)$

mass) varied only slightly at $\mathrm{SB}_{\mathrm{A}}$, while it showed evident seasonal variability at $\mathrm{SB}_{\mathrm{B}}$ and $\mathrm{SB}_{\mathrm{C}}$ (Fig. 5a,b). The same overall seasonal trend occurred for the mean species richness for the 3 SBs (Fig. 5c) with the highest mean $S$ observed in August and September for each site. The mean Shannon and
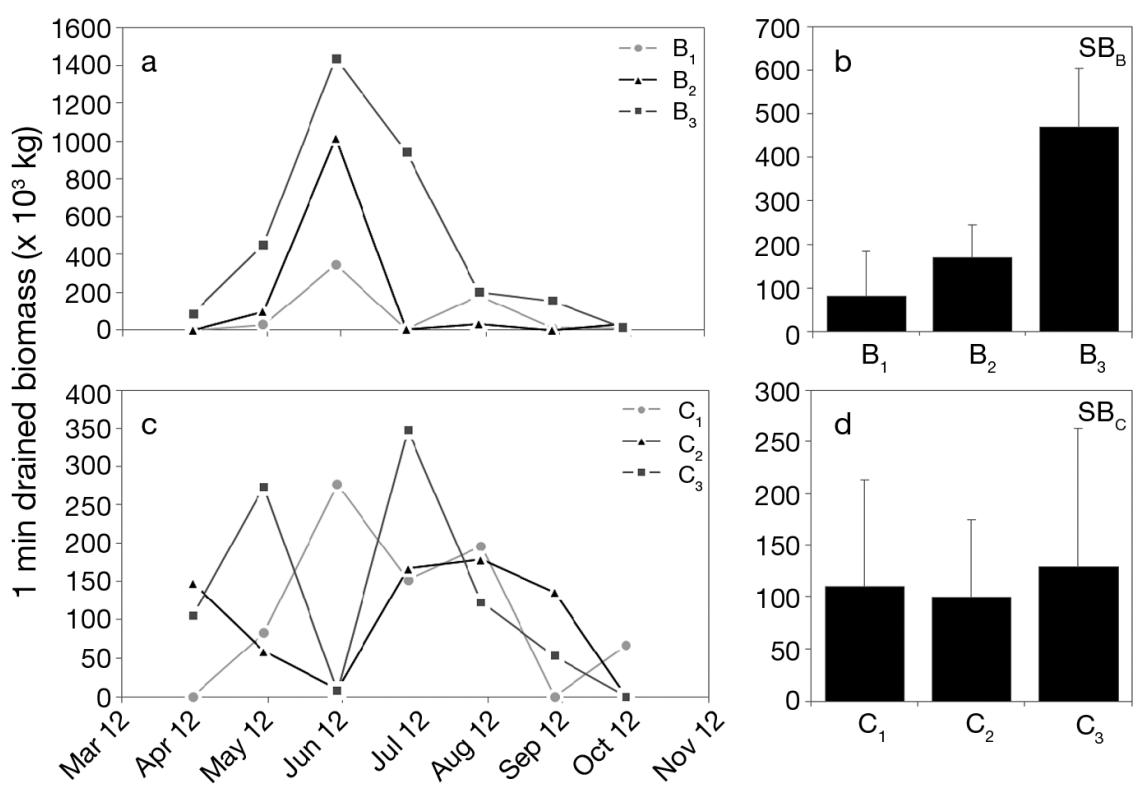

Fig. 3. Monthly biomass of stranded Ulva throughout the year 2012 estimated at (a) $\mathrm{SB}_{\mathrm{B}}$ and (c) $\mathrm{SB}_{\mathrm{C}}$ and yearly mean $\left( \pm \mathrm{SD}\right.$ ) at (b) $\mathrm{SB}_{\mathrm{B}}$ and (d) $\mathrm{SB}_{\mathrm{C}}$. Note that the scales are not the same on all plots
Simpson indices showed seasonal variability (Fig. 5d,e) with lower levels at $\mathrm{SB}_{\mathrm{B}}$ and $\mathrm{SB}_{\mathrm{C}}$ from August to February.

\section{Disentangling effects of time, space, and environment on univariate responses}

Variation partitioning revealed the proportion of variation of the 5 univariate community responses $\left(A, B, S, H^{\prime}\right.$, and $D$ ) explained by temporal variables $[\mathbf{T}]$, spatial variables $[\mathbf{S}]$, environmental variables $[\mathbf{E}]$, and their combinations, for the 3 sandy beaches (Table 2, see Fig. S2 in the Supplement for an example of associated Venn diagram). Taken together, the 3 explanatory variables matrices $([\mathbf{T}]+$ $[\mathbf{S}]+[\mathbf{E}])$ significantly explained a large amount (26 to $86 \%, \mathrm{p}<0.05$ ) of 

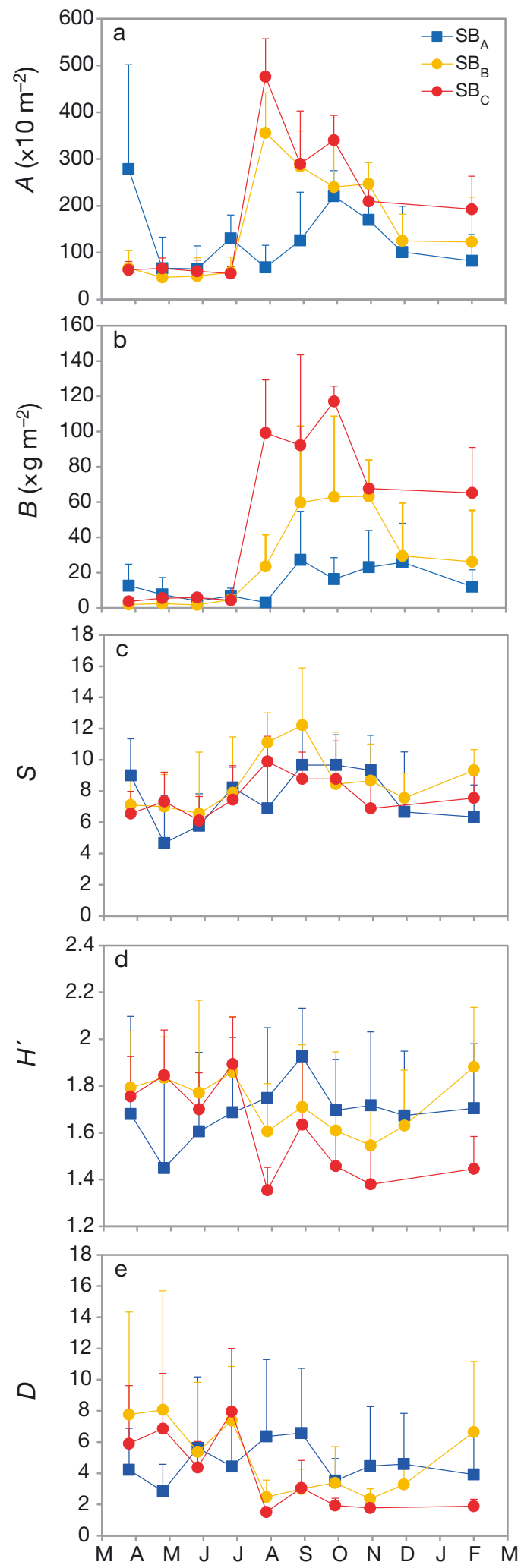

Fig. 5. Mean (+SD) abundance $(A)$, biomass $(B)$, species richness $(S)$, numerical equivalents of Shannon's entropy $\exp \left(H^{\prime}\right)$ and Simpson's (1/D) indices (after Jost 2006) from April 2012 to February 2013 at the 3 beaches $\left(\mathrm{SB}_{\mathrm{A}}, \mathrm{SB}_{\mathrm{B}}\right.$ and $\left.\mathrm{SB}_{\mathrm{C}}\right)$ the variation observed in univariate responses of the 3 beaches considered in this study, especially for $\mathrm{SB}_{\mathrm{C}}$ (Table 2).

Considering the variables separately, temporal, spatial, and environmental variables explained univariate community variables for $\mathrm{SB}_{\mathrm{A}}$ and $\mathrm{SB}_{\mathrm{B}}$ in the vast majority of situations. Nevertheless, the number of occasions on which the variation explained by spatial explanatory variables was non-significant was higher in $\mathrm{SB}_{\mathrm{B}}$ than in $\mathrm{SB}_{\mathrm{A}}$, and significant models explained less variation. More remarkably, spatial variables did not significantly explain any variation observed in univariate responses for $\mathrm{SB}_{\mathrm{C}}$, where only temporal and environmental explanatory variables significantly explained variations (Table 2).

The small proportions of variation explained by 'pure' explanatory variables (Table 2) indicated that temporal and environmental variables shared high portions of explained variance. The environmental variables [E] consisted of both physical and biological factors whose significance in explaining variations in the univariate variables $\left(A, B, S, H^{\prime}\right.$, and $\left.D\right)$ was tested for each SB (Table 3). Salinity, dissolved oxygen, mean wave height, and beach slope were the variables most useful to model the variation in the univariate variables observed at $\mathrm{SB}_{\mathrm{A}}$. $\mathrm{SB}_{\mathrm{B}}$ diversity patterns were best matched with Ulva biomass, total organic matter content, phytoplankton, and with the dissolved oxygen content, seawater temperature, and the slope. The same patterns were observed for $\mathrm{SB}_{\mathrm{C}}$, but the number of environmental factors fitting the univariate response variation rose.

\section{Community composition and its dynamics related to time, space, and environment}

The 21 species presented in Table 4, which mainly belong to molluscs, polychaetes, and crustaceans, made up almost all (99.9\%) of the total biomass observed at each of the 3 SBs. The sandy beach community across the 3 SBs is dominated by 3 suspension-feeding bivalves (Table 4) whose contribution to the total biomass differed among the beaches. Where green tides landed on shore $\left(\mathrm{SB}_{\mathrm{B}}\right.$ and $\left.\mathrm{SB}_{\mathrm{C}}\right)$, Donax vittatus largely contributed to the total biomass, while D. trunculus and Angulus tenuis were underrepresented, opposite to $\mathrm{SB}_{\mathrm{A}}$. The same distinction between beaches was detected for echinoderms (Acrocnida brachiata), surface deposit-feeding annelids (Spiophanes bombyx vs. Owenia fusiformis), and carnivorous polychaetes (Nephtys hombergii and Glycera tridactyla vs. Lumbrinereis sp.). 
Table 2. Variance partitioning of total abundance $(A)$, total biomass $(B)$, total species richness $(S)$, Shannon index $\left(H^{\prime}\right)$, and Simpson's index $(D)$ of the 3 beaches $\left(\mathrm{SB}_{\mathrm{A}}, \mathrm{SB}_{\mathrm{B}}\right.$, and $\left.\mathrm{SB}_{\mathrm{C}}\right)$. Variation explained is expressed as a percentage $(\%)$ based on adjusted $\mathrm{R}^{2}$. [T]: selected temporal variables; [S]: spatial location along beaches; [E]: environmental variables; Unexpl.: unexplained variation. Degrees of freedom for $[\mathbf{S}]=2$, for $[\mathbf{E}]=10$, and varied from 1 to 6 for $[\mathbf{T}]$ due to the forward selection. Grey italicized numbers represent non-significant fractions. The shaded cells show the significant $(p<0.05)$ contributions of explanatory matrices that explain the variation observed in the univariate variables

\begin{tabular}{|c|c|c|c|c|c|c|c|c|c|c|c|c|c|c|c|}
\hline \multirow[t]{2}{*}{ Variable } & \multicolumn{5}{|c|}{$\mathrm{SB}_{\mathrm{A}}$} & \multicolumn{5}{|c|}{$\mathrm{SB}_{\mathrm{B}}$} & \multicolumn{5}{|c|}{$\mathrm{SB}_{\mathrm{C}}$} \\
\hline & $A$ & $B$ & $\begin{array}{l}S \\
\%\end{array}$ & $H^{\prime}$ & $D$ & $A$ & $B$ & $\begin{array}{c}S \\
\%\end{array}$ & $H^{\prime}$ & $D$ & $A$ & $B$ & $\begin{array}{c}S \\
\%\end{array}$ & $H^{\prime}$ & $D$ \\
\hline$[\mathbf{T}+\mathbf{S}+\mathbf{E}]$ & 48 & 74 & 42 & 26 & 28 & 68 & 67 & 34 & 25 & 19 & 86 & 84 & 34 & 62 & 73 \\
\hline$[\mathbf{T}]$ & 26 & 29 & 21 & 4 & 20 & 67 & 63 & 21 & 10 & 22 & 84 & 84 & 28 & 52 & 64 \\
\hline$[\mathbf{S}]$ & 9 & 36 & 16 & 21 & 0 & 0 & 1 & 8 & 17 & 0 & 0 & 0 & 2 & 1 & 5 \\
\hline [E] & 15 & 50 & 16 & 6 & 14 & 62 & 62 & 15 & 8 & 18 & 72 & 75 & 33 & 45 & 44 \\
\hline$[\mathbf{T} \mid(\mathbf{S}+\mathbf{E})]$ & 31 & 10 & 17 & 0 & 14 & 6 & 3 & 10 & 0 & 0 & 13 & 9 & 2 & 16 & 21 \\
\hline$[\mathbf{S} \mid(\mathbf{T}+\mathbf{E})]$ & 0 & 7 & 8 & 21 & 0 & 0 & 1 & 12 & 18 & 0 & 0 & 0 & 0 & 0 & 4 \\
\hline$[\mathbf{E} \mid(\mathbf{T}+\mathbf{S})]$ & 11 & 6 & 5 & 0 & 8 & 0 & 1 & 4 & 0 & 0 & 2 & 0 & 3 & 7 & 1 \\
\hline Unexpl. & 52 & 26 & 58 & 74 & 72 & 32 & 33 & 66 & 75 & 76 & 14 & 16 & 66 & 38 & 27 \\
\hline
\end{tabular}

Table 3. Variation in total abundance $(A)$, biomass $(B)$, species richness $(S)$, transformed Shannon index $\left(H^{\prime}\right)$, and transformed Simpson index $(D)$ for the 3 beaches $\left(\mathrm{SB}_{\mathrm{A}}, \mathrm{SB}_{\mathrm{B}}\right.$, and $\mathrm{SB}_{\mathrm{C}}$ ) explained by stepwise regression models constructed with all environmental variables. Bold variables are those that enter at least 2 distinct models. SWT: seawater temperature; P: physicochemical variable; B: biological variable ${ }^{*} \mathrm{p}<0.05,{ }^{* *} \mathrm{p}<0.01,{ }^{* * *} \mathrm{p}<0.001$

\begin{tabular}{|c|c|c|c|c|c|c|}
\hline & Type & $A$ & $B$ & $S$ & $H^{\prime}$ & $D$ \\
\hline $\begin{array}{l}\mathbf{S B}_{\mathbf{A}} \\
\text { SWT }\left({ }^{\circ} \mathrm{C}\right)\end{array}$ & Adj R²: & 14.2 & 35.9 & 7.0 & \multirow[t]{10}{*}{1.6} & \multirow[t]{2}{*}{13.0} \\
\hline Salinity (psu) & $\mathbf{P}$ & $* *$ & $* *$ & $* *$ & & \\
\hline Dissolved $\mathrm{O}_{2}(\%)$ & $\mathbf{P} / \mathbf{B}$ & $* *$ & & & & \multirow[t]{8}{*}{$* * *$} \\
\hline Ulva biomass (t) & B & & & & & \\
\hline Mean wave height (m) & $P$ & & $* *$ & $*$ & & \\
\hline Sorting index (unitless) & s) $\mathrm{P}$ & & & & & \\
\hline Slope (\%) & $\mathbf{P}$ & $*$ & $* * *$ & & & \\
\hline Organic matter (\%) & B & & * & & & \\
\hline Phytoplankton $\left(\mu \mathrm{g} \mathrm{l}^{-1}\right)$ & $\mathrm{B}$ & & $* * *$ & & & \\
\hline Median $(\mu \mathrm{m})$ & $\mathrm{P}$ & & & & & \\
\hline $\operatorname{Adj} R^{2}$ : & Adj $R^{2}$ : & 59.7 & 59.9 & 11.3 & \multirow[t]{4}{*}{11.1} & \multirow[t]{4}{*}{14.0} \\
\hline SWT $\left({ }^{\circ} \mathrm{C}\right)$ & $\mathbf{P}$ & $* * *$ & $* * *$ & & & \\
\hline Salinity (psu) & $\mathrm{P}$ & & & & & \\
\hline Dissolved $\mathrm{O}_{2}(\%)$ & P/B & $* * *$ & $* * *$ & & & \\
\hline Ulva biomass (t) & B & $* *$ & $* *$ & $* *$ & * & $* *$ \\
\hline Mean wave height (m) & ) $\mathrm{P}$ & $* * *$ & & & & \\
\hline Sorting index (unitless) & S) $\mathrm{P}$ & & & & & \\
\hline Slope $(\%)$ & $\mathbf{P}$ & & $* * *$ & & * & ** \\
\hline Organic matter (\%) & B & & & & $* *$ & * \\
\hline Phytoplankton $\left(\mu \mathrm{g} \mathrm{l}^{-1}\right)$ & $\mathbf{B}$ & $* * *$ & $* * *$ & $* *$ & & \\
\hline Median $(\mu \mathrm{m})$ & $\mathrm{P}$ & & & & & \\
\hline $\operatorname{Adj} R^{2}$ & Adj $\mathbf{R}^{2}$ : & 66.9 & 72.0 & 30.8 & \multirow[t]{4}{*}{36.3} & \multirow[t]{4}{*}{33.5} \\
\hline $\operatorname{SWT}\left({ }^{\circ} \mathrm{C}\right)$ & $\mathbf{P}$ & $* * *$ & $* * *$ & $* * *$ & & \\
\hline Salinity (psu) & $\mathbf{P}$ & $* * *$ & $* * *$ & $* * *$ & & \\
\hline Dissolved $\mathrm{O}_{2}(\%)$ & P/B & $* * *$ & $* * *$ & $* * *$ & & \\
\hline Ulva biomass (t) & B & $*$ & $*$ & & $* *$ & * \\
\hline Mean wave height (m) & l) $P$ & $* * *$ & $* * *$ & $* * *$ & $* *$ & $* *$ \\
\hline Sorting index (unitless) & S) $\mathrm{P}$ & & & & & \\
\hline Slope $(\%)$ & $\mathrm{P}$ & & & & & \\
\hline Organic matter (\%) & B & & & ** & $* * *$ & $* * *$ \\
\hline Phytoplankton $\left(\mu \mathrm{g} \mathrm{l}^{-1}\right)$ & $\mathbf{B}$ & $* * *$ & $* * *$ & $* * *$ & & \\
\hline Median $(\mu \mathrm{m})$ & $\mathrm{P}$ & & & & & \\
\hline
\end{tabular}

A significant interaction between time and beach on macrofauna community structure was revealed by the 2 -factor MANOVA $\left(F_{14,48}=1.42, \mathrm{p}=0.006\right)$. Consequently, we focused on each of the 3 beaches separately to look at the spatio-temporal changes in the benthic communities.

BDTotal varied among the 3 beaches. There was no significant Kendall correlation between total $\beta$-diversity and Ulva coverage ( $\tau=-0.08, \mathrm{p}=0.30, \mathrm{n}=24$ ) considering all sampling events. However, a significant difference in $\beta$-diversity was found between $\mathrm{SB}_{\mathrm{A}}$ (no green tide present during any of the sampling times) and $\mathrm{SB}_{\mathrm{C}}$ (uniform Ulva coverage along the shore; $W=54$, corrected $p=0.021$ ). The median of total $\beta$-diversity was the highest when Ulva never occurs on shore, and the lowest was found where green tide occurs homogeneously along the shore (Fig. 6). $\mathrm{SB}_{\mathrm{B}}$, with a local persistent gradient in Ulva coverage along the shore, had an intermediate BDTotal value and exhibited a greater dispersion than $\mathrm{SB}_{\mathrm{A}}$ and $\mathrm{SB}_{\mathrm{C}}$ (Fig. 6). $\mathrm{SB}_{\mathrm{B}}$ did not significantly differ from $\mathrm{SB}_{\mathrm{A}}(W=46$, corrected $\mathrm{p}=0.321)$ or $\mathrm{SB}_{\mathrm{C}}$ $(W=45$, corrected $\mathrm{p}=0.321)$.

Shifts and differences in community structure between the 3 beaches are illustrated with PCA analyses (Fig. 7), integrating time (range of grey scale) and space in the representation (3 different shapes for sites). On one hand, the ordination for $\mathrm{SB}_{\mathrm{A}}$ showed the absence of a clear temporal pattern and both distinct and overlapping spatial structuring of macrofaunal data (Fig. 7A). On the other hand, a different picture emerges for $\mathrm{SB}_{\mathrm{B}}$ and $\mathrm{SB}_{\mathrm{C}}$ (Fig. $7 \mathrm{~B}, \mathrm{C}$ ) with a shift in benthic community composition over time and a spatial structuring for $\mathrm{SB}_{\mathrm{B}}$ macrofauna communities. No discernible spatial patterns appeared at $\mathrm{SB}_{\mathrm{C}}$. 


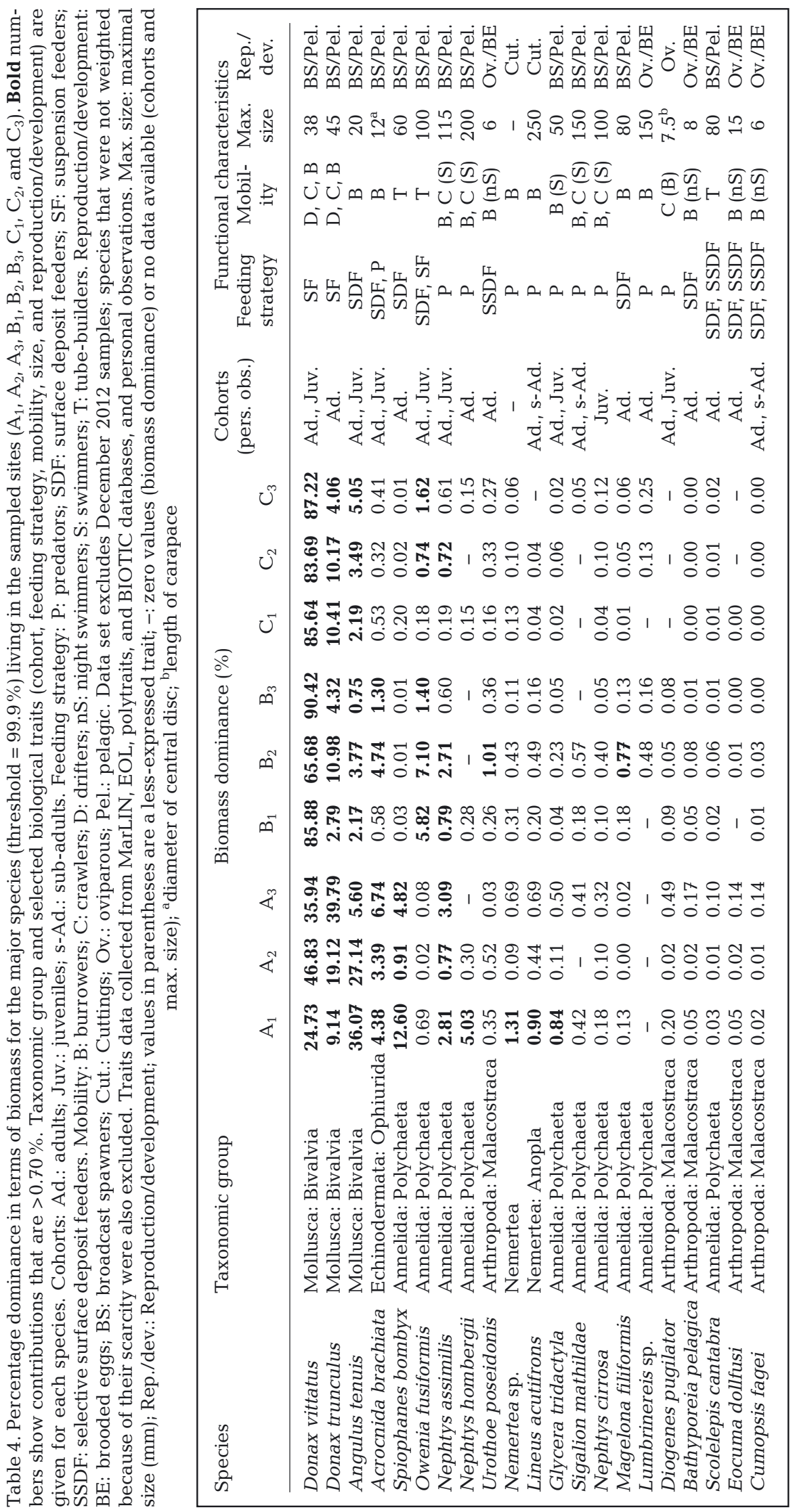

Partitioning of the variance of macrofauna at the 3 SBs with respect to temporal, spatial, and environmental explanatory variables is presented in Fig. 8. The proportion of variation explained by the combination of the 3 sets of explanatory variables was always significant and increased from $\mathrm{SB}_{\mathrm{A}}$ to $\mathrm{SB}_{\mathrm{C}}$ (35 to $42 \%$, $p<0.05)$. This increase is mainly attributable to a better fit of the temporal and environmental variables to the variation in the macrofauna community observed at sandy beaches harbouring green tides, and may be illustrated by the increase in the explanatory power of the intersection of time and environment from $\mathrm{SB}_{\mathrm{A}}$ to $\mathrm{SB}_{\mathrm{C}}(12$ to $28 \%, \mathrm{p}<0.05)$. Spatial variables (total and pure fractions) also significantly explained the variation observed in macrozoobenthic assemblages. However, the spatial explanatory power decreased from $\mathrm{SB}_{\mathrm{A}}$ to $\mathrm{SB}_{\mathrm{C}}(9$ to $3 \%, \mathrm{p}<0.05)$.

These results all corroborate the hypothesis that time and space play a major role in explaining benthic assemblage structure at $\mathrm{SB}_{\mathrm{A}}$ and $\mathrm{SB}_{\mathrm{B}}$, while the location along the shore does not explain macrofauna community structure observed at $\mathrm{SB}_{\mathrm{C}}$, which has the most uniform cover of Ulva.

The correlation triplot of redundancy analysis of macrofaunal data from all 3 beaches, constrained by time, space, and environment (Fig. 9), revealed 3 dot clouds: a triangular polygon on the top-right contained the $\mathrm{SB}_{\mathrm{A}}$ sites, and 2 diagonals in the centre and in the lower part of the diagram were formed by $\mathrm{SB}_{\mathrm{C}}$ and $\mathrm{SB}_{\mathrm{B}}$ sites. The separation of the 3 sites is associated with the explanatory variables SI, oxygen content, and Ulva biomass. The ordination diagrams (Fig. 9) also showed strong and positive association of the SI and Angulus tenuis and Spiophanes bombyx, of wave height and Donax vittatus, and of Ulva biomass and Magelona filiformis. 


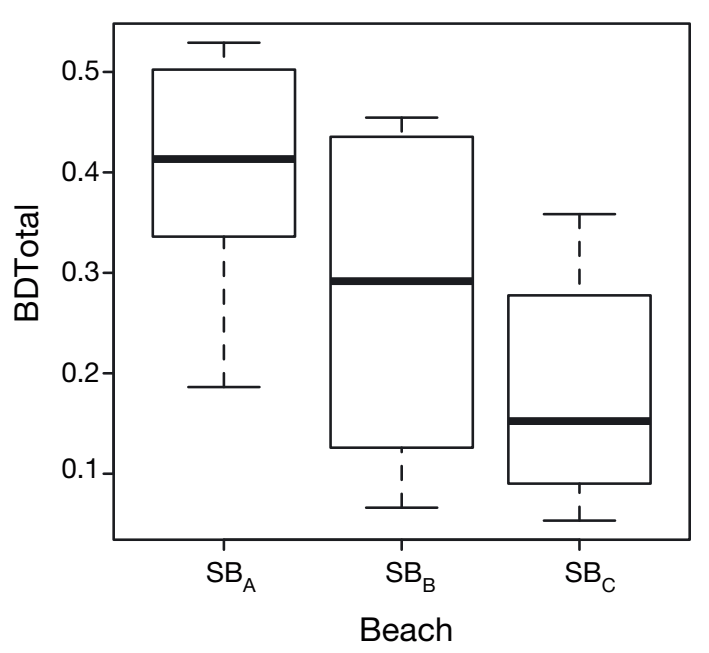

Fig. 6. Total $\beta$-diversity (BDTotal) across space and time at the 3 beaches $\left(\mathrm{SB}_{\mathrm{A}}, \mathrm{SB}_{\mathrm{B}}\right.$ and $\left.\mathrm{SB}_{\mathrm{C}}\right)$. Box plots show the median (line in box), the first and third quartiles (hinges), and the most extreme data points which are 1.5 times the interquartile range from the box (whiskers)

\section{DISCUSSION}

Macrozoobenthic assemblages of the oceanexposed sandy beaches considered in this study were mainly composed of molluscs, polychaetes, and crustaceans, which is consistent with other studies in the same ecoregion (Leber 1982, Degraer et al. 1999, Rodil et al. 2006) and worldwide (e.g. McLachlan 1983). The SBs had a rich benthic community, composed of $>60$ species, and it was highly variable along the shore and through time. Spatio-temporal changes in the overall community composition support our hypotheses 1 and 2, indicating that macrotidal SB macrofauna community structure is dependent on site at small spatial scales (hundreds of meters) and time of the year (monthly to seasonal intervals).

More precisely, the 3 sites that we studied along the swash zone of $\mathrm{SB}_{\mathrm{A}}$ (no green tides present at any time of the year on any site) showed similar rarefied species richness, while other biological variables, such as biomass and abundance, varied among sites. Similar species richness among sites may be explained by homogenisation, which is an important factor in determining intertidal macrobenthic community patterns (de Juan \& Hewitt 2014). Along-shore patterns observed in abundance and biomass have also been described for other sandy shores (Defeo \& de Alava 1995) and may be associated with gradients in physical (e.g. swash climate) and biological (e.g. competition or predation) factors (Defeo \& McLachlan 2005).
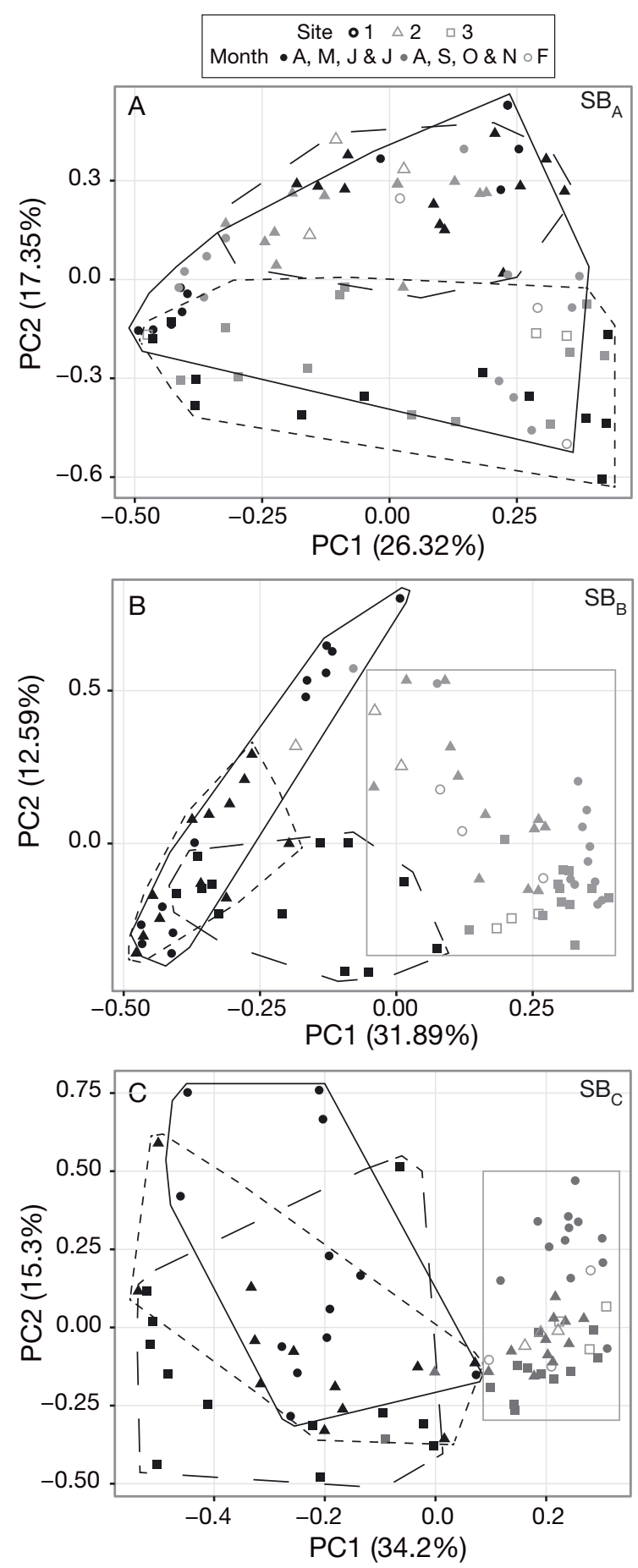

Fig. 7. Principal component analysis (PCA) distance biplots (i.e. scaling 1) of Sites 1 (circles), 2 (triangles), and 3 (squares), based on Hellinger-transformed abundance of benthic community sampled at $\mathrm{SB}_{\mathrm{A}}, \mathrm{SB}_{\mathrm{B}}$ and $\mathrm{SB}_{\mathrm{C}}$ from April 2012 to February 2013 (excluding December 2012 for balanced design) with superimposed indicative clusters for spatial (solid line [Site 1], dashed line [Site 2] or long-dashed line [Site 3] polygons) and/or temporal structuring (grey boxes and symbols for autumn/winter, highlighting the difference from spring/summer [black polygons and symbols]) 

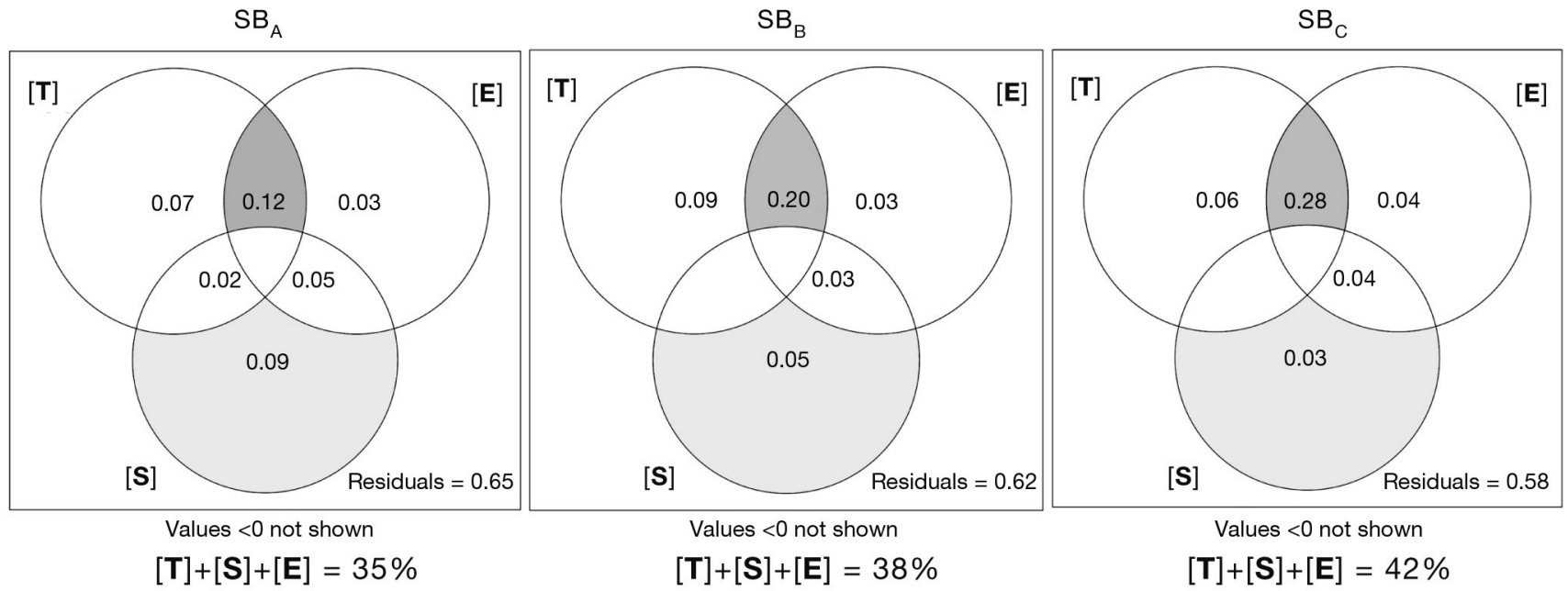

Fig. 8. Venn diagrams illustrating the result of variance partitioning of the macrofauna time series at $\mathrm{SB}_{\mathrm{A}}, \mathrm{SB}_{\mathrm{B}}$, and $\mathrm{SB}_{\mathrm{C}}$ with respect to environmental (physical and biological variables), spatial (location along shore), and temporal (distance-based Moran's eigenvector maps [dbMEMs]) explanatory variables. Variation explained is expressed as a percentage (\%) based on adjusted

$\mathrm{R}^{2}$. [T]: selected temporal variables, [S]: spatial location, [E]: environmental variables, Residuals: unexplained variation

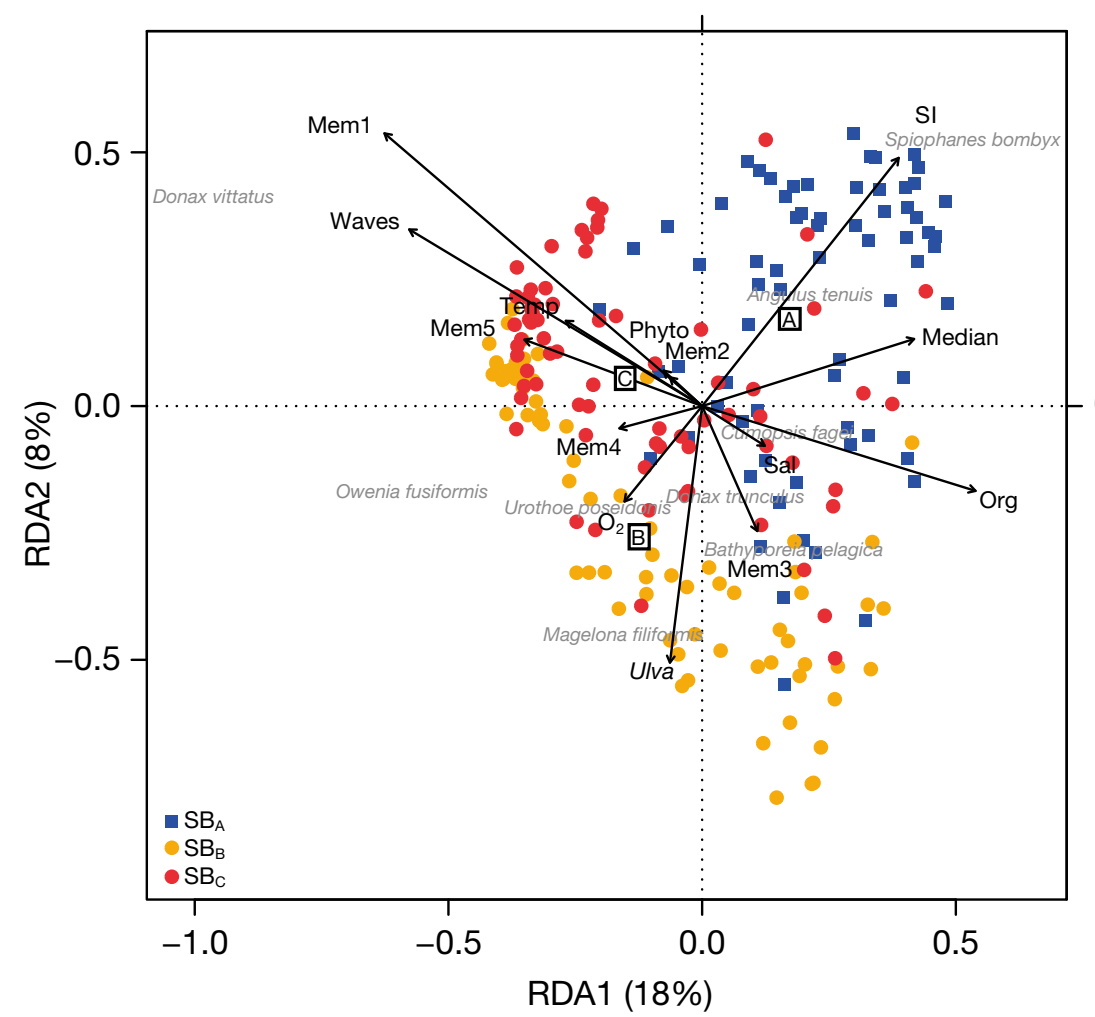

Fig. 9. RDA correlation triplot (scaling 2) of macrofaunal communities data and all explanatory variables (environmental, spatial, and temporal) of the 3 sandy beaches together: A (blue), B (orange), and C (red). Org: total organic matter; Sal: salinity; $\mathrm{O}_{2}$ : dissolved oxygen; Temp: temperature; Phyto: phytoplankton concentration; Median: Q50 (second quartile of the sediment grain size); SI: sorting index calculated based on first and third quartile ratio ( $\sqrt{ } \mathrm{Q} 25 / \mathrm{Q} 75$, where Q25 and Q75 denote the first and the third quartiles of the sediment grain size, respectively); Ulva: stranded Ulva biomass; Waves: wave height; Mem $x$ : temporal variable $x$ generated dbMEM eigenfunctions, $x$ : centroid for SBs
Variation partitioning also revealed the significant importance of spatial variables in explaining the variation observed for univariate variables calculated from macrofaunal data. Along-shore variations of the primary community variables and diversity indices were due to changes in the relative abundance (recruitment) of key species such as Donax vittatus and Owenia fusiformis. These changes in the spatial variation of the univariate variables of the benthic community are consistent with the findings of James \& Fairweather (1996), who highlighted significant along-shore variation in the abundance of individual taxa. More recently and at smaller spatial scales (transects about $10 \mathrm{~m}$ apart), Veiga et al. (2014) also found variability in the abundance, diversity, and structure of macrobenthic assemblages. Our study argues in favour of small spatial (hundreds of meters) along-shore structuring of macrotidal SB macrofauna. Taking into consideration along-shore variation through entire open sandy beaches is thus crucial for ecological studies aiming at understanding the functioning of such systems at the mesoscale. 


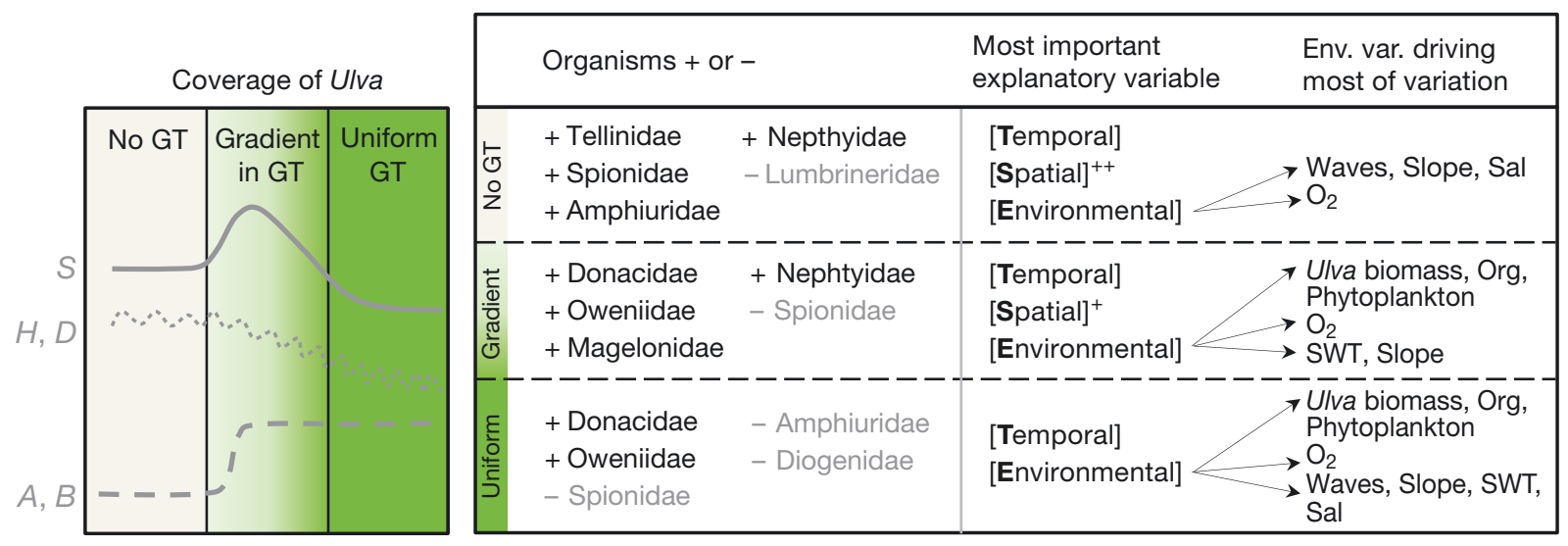

Fig. 10. Conceptual model of the effects of green tides on macrobenthic characteristics of sandy beaches. GT: green tide; Env.: environmental; var.: variable; +: stimulated; -: stifled; SWT: seawater temperature; $S$ : species richness; $H^{\prime}, D$ : Shannon and Simpson indices; A, B: abundance and biomass; Waves: wave height; Sal: salinity; Org: total organic matter

Also, temporal variables influenced abundance, biomass, and species richness at $\mathrm{SB}_{\mathrm{A}}$. These observations are in accordance with other studies in comparable environments (Leber 1982, Degraer et al. 1999), although such studies often do not take small temporal scale into consideration. Our results highlight real seasonal patterns (Morrisey et al. 1992) in the benthic community as we sampled intensively (monthly) during each season. The seasonal variations observed are mainly due to recruitment of the dominant species during summer (Guillou 1982, McLachlan \& Brown 2006) as well as mortality and migrations offshore due to lower temperature and storms during winter (McLachlan \& Brown 2006). Furthermore, temporal changes in the benthic macrofauna structure may be modified by variations in the food supply and by trophic interactions within the zoobenthos (Defeo \& McLachlan 2005). Our results emphasize the importance of covering the small temporal scale (month).

Our third hypothesis, regarding changes occurring in the presence of Ulva macroalgal mats, was verified (Fig. 10). Our results support the hypothesis that patterns and differences in macrofaunal community structure observed arose from an Ulva accumulation gradient on sandy shores rather than from other environmental factors. Indeed, most of the environmental variables (wave height, seawater temperature, salinity, dissolved oxygen, slope, and phytoplankton) did not show any significant differences among the 3 beaches or over time. Median grain size and sorting were significantly different, but the effect sizes are negligible when placed in an ecological context: both characterized fine and well-sorted sediments (Blott \& Pye 2001). Furthermore, organic matter content dif- fered among the 3 SBs due to temporal variations (see Fig. S5 in the Supplement at www.int-res.com/ articles/suppl/m522p097_supp.pdf) that may be linked to the presence of Ulva stranded ashore. Indeed, accumulations of drifting macroalgae cause direct shading of sandy shores, which limits the growth of microphytobenthos (Corzo et al. 2009). A loss of microalgal mats may thus result in a decrease in total organic matter content, and since microphytobenthos support grazing trophic levels (Miller et al. 1996), it may also affect deposit-feeding macrofauna. The 3 beaches are part of the same regional macrohabitat (Glémarec 1969), but despite being located in the same regional water body and showing high similarities in terms of physical characteristics, the 3 beaches showed different nutrient concentrations in the inshore water (Dussauze \& Ménesguen 2008). Due to agricultural activity in the catchment area, coastal rivers draining at $\mathrm{SB}_{\mathrm{B}}$ and $\mathrm{SB}_{\mathrm{C}}$ bring nutrients. There, the eutrophication and the associated Ulva blooms originating from nutrient inputs remain highly local, i.e. hundreds of meters from the shore at the mouths of coastal rivers (Ménesguen \& Piriou 1995).

In the present study, the rarefied richness differed among beaches. The beach where a gradient in Ulva stranding occurred $\left(\mathrm{SB}_{\mathrm{B}}\right)$ exhibited higher rarefied species richness than was found at $\mathrm{SB}_{\mathrm{A}}$ which did not harbour green macroalgal blooms. Where Ulva mats occurred homogeneously along the shore $\left(\mathrm{SB}_{\mathrm{C}}\right)$, the rarefied species richness was lowest (Fig. 4). The observed patterns are in line with what would be expected from the benthic successional paradigm on the effects of increasing organic-matter inputs on communities of benthic macrofauna (Pearson \& Rosenberg 1978). This model shows an increase in 
benthic species richness, numerical abundance, and biomass with moderate perturbation and then a decrease when disturbance increases, which is in accordance with the concept of intermediate disturbance (Connell 1978).

While it is well recognized that accumulation of macroalgae has strong negative effects on sedentary infauna (Raffaelli et al. 1998, Grall \& Chauvaud 2002), such as widespread mortality in zoobenthic communities (Everett 1994, Norkko \& Bonsdorff 1996, Bolam et al. 2000), our results contradict this paradigm for the intertidal flats of exposed macrotidal sandy beaches (Fig. 10). In our study, in the highest eutrophic conditions, i.e. under very dense Ulva mats ( 1.5 kg m${ }^{-2}$, Fig. 1), the community response was not as evident as one would have expected. The subtle response of SB macrofauna to eutrophication by Ulva accumulation is probably due to the highly dynamic nature of SBs. To highlight these elusive, but real, changes in SB communities, classical ecological and statistical approaches have proved to be inefficient. Our study shows that the combination of a fine spatial-temporal monitoring of the benthic community reaching a high number of samples together with novel statistical approaches (dbMEMs and variation partitioning; Borcard \& Legendre 1994, Dray et al. 2006, Legendre \& Gauthier 2014) were essential in understanding the changes occurring in SB systems under eutrophication stress.

Following the approach described above, our results also suggest that increasing coverage of stranded Ulva along the shores induces a homogenization of the forces driving the swash-zone benthic community structure (Fig. 10). Compared to a state with no Ulva, a large and homogeneous coverage of Ulva along the shore induces a significant decrease of overall $\beta$-diversity and, eventually, a complete lack of spatial pattern in community composition. Where no green tides occurred, 3 main drivers [T, $\mathbf{S}$, and $\mathbf{E}$ ] influenced the responses of the benthic community, while where algal mats stranded homogeneously along the shore $\left(\mathrm{SB}_{\mathrm{C}}\right)$, community structure was mainly driven by time and environment, including the macroalgae. To fully distinguish ecological patterns observed at macrotidal sandy beaches where green tides have occurred, a longer time-span of the sampling would be required.

Furthermore, a stepwise regression model for univariate diversity indices supports the idea that in regions where no green tide occurred, the main retained environmental variables were physical factors, which is in accordance with previous studies (e.g. Defeo \& McLachlan 2005, McLachlan \& Dorvlo
2005, McLachlan \& Brown 2006). However, our results also highlight the increasing contribution of biological factors along a gradient of increasing coverage of stranded Ulva, which corroborates the hypothesis that sandy beach community structure is not only driven by physical factors but also explained by factors linked to general coastal processes (Lastra et al. 2006), competition (Dugan et al. 2004), predation (McLachlan \& Brown 2006), and other biological interactions at small spatial and temporal scales.

While our results highlight the subtle nature of the responses of sandy beach systems to strong eutrophication, community composition varied among the 3 beaches considered in this study. Fewer species dominated where green tides occurred, an observation that may be linked to 'biotic homogenization', defined as the process by which human-induced disturbances increase the taxonomic or functional similarity of environments (Smart et al. 2006). In this respect, our results are consistent with other studies showing the effects of algal accumulation on benthic communities (e.g. Hull 1987, Raffaelli et al. 1998, Bolam et al. 2000). The species-dominance patterns also changed with increasing algal cover (Fig. 10). The densities of Donax trunculus were lower where green tides occurred. Because this species is of commercial importance (Augris et al. 2005, McLachlan \& Brown 2006), the green tides also negatively influence human use and value of the beaches. Moreover, sandy beaches are essential habitat for flatfish recruitment and nursery (Besyst et al. 1999, Rabaut et al. 2013). Spionids are considered essential polychaete prey and important trophic support in fish nursery grounds (Speybroeck et al. 2007). Considering that spionid abundance is impacted negatively by the presence of Ulva mats, the nursery-area function of SBs could be affected. Consequently, questions may arise about the potential indirect cascading effects of the presence of algal mats on clam and flatfish fisheries.

Our results also suggest that the high abundance of Donax vittatus, which is not a commercial species, at $\mathrm{SB}_{\mathrm{B}}$ and $\mathrm{SB}_{\mathrm{C}}$ is probably linked to the presence of Ulva mats. In the early $1980 \mathrm{~s}$, the recruitment was defined as 'very important', with densities reaching 1000 ind. $\mathrm{m}^{-2}$ at $\mathrm{SB}_{\mathrm{C}}$ (Guillou 1982). Similar densities for $D$. vittatus recruits were found at Ile d'Oléron (French Atlantic coast) over the same period (Ansell \& Lagardère 1980). Thirty years later, when green tides are common at eutrophic SBs (Ye et al. 2011), we found densities comprised 1800 to 5000 ind. $\mathrm{m}^{-2}$ at each of the 6 sites influenced by green tides. The abundance peak of $D$. vittatus may be attributable to 
the influence of macroalgal mats on local hydrodynamics favouring higher recruitment, as suggested by Hull (1987). In addition, because the presence of Ulva mats induced a decrease in $D$. trunculus (Table 4) and because interspecific competition for space exists between the 2 Donacidae species (Guillou 1982), D. vittatus could find an available niche at SBs where macroalgae get stranded. Also, macroalgal mats induce a decrease of the foraging success of juvenile flatfish (Nordström \& Booth 2007) and of the biomass of polychaete predators (Table 4 ; results in line with Weston 1990); consequently, predation pressure on $D$. vittatus recruits decreases, which may explain the high abundance of the bivalve where green tides occurred.

Besides these shifts in benthic community composition, changes in terms of biomass dominance of species within SBs where detached Ulva was washed ashore indicated changes in community biological trait expression (Table 4). For example, animals defined as surface-deposit feeders or suspension feeders dominated the community at SBs with green tides, while predators consistently contributed to SB communities where no green tide occurred. These results, although subtle, are in line with the biomass profile drawn by Weston (1990) showing the relative dominance of the major polychaete trophic groups with increasing organic matter inputs. More explicit hypotheses of shifts in marine community functioning could be tested using appropriate tools, such as stable isotopes and biological trait analysis (Grall et al. 2006, Törnroos \& Bonsdorff 2012).

The effects of macroalgae accumulation on highly dynamic systems such as macrotidal sandy beaches are poorly known, but our results are in line with those from Hull (1987) and with those on wrack (i.e. stranded near-shore macroalgal and seagrass accumulations) subsidies studies at upper-shore regions (Soares et al. 1997, Colombini et al. 2000, Dugan et al. 2003). For example, Gonçalves et al. (2009) discussed possible effects of detritus accumulation on the structure of sandy beach benthic communities and the influence of exogenous supply on the structure of macrofauna assemblages. To our knowledge, our work is the first to demonstrate that detritus/macroalgal deposits influence lowshore communities.

\section{CONCLUSIONS}

The present study demonstrates that swash-zone macrobenthic community structure in macrotidal sandy beaches is dependent on both location along the shore (at small spatial scale, hundreds of meters apart) and on seasonal variations (monthly). Our results thus clearly recommend taking into account interacting spatial and temporal variation in the study of SB macrofauna assemblages. Moreover, our work highlights the importance of biotic interactions in environments characterized by strong physical forces and fluctuating conditions. This result is important because sandy beach ecology often considers that biological processes do not play a fundamental role in explaining macrofaunal community structure, in contrast to physical factors. Furthermore, our study shows that the presence of Ulva mats induces (1) an homogenization of the community living at lower-shore of SBs, (2) a stimulation of the recruitment of some dominant species, and (3) a decrease in the abundance of species assuming key roles for the functioning of SB ecosystems. However, the responses of macrofauna to Ulva accumulation are dependent on the type of green tide stranded along the shore (with a gradient in biomass of stranded macroalgae or not) and were not as distinct as in more sheltered systems. The effects of strong eutrophication on benthic community structure vary considering hydrodynamics, from a distinct deterioration (sheltered environments) to more subtle impacts (open systems). Thus, our study highlights the context-dependency of effects of macroalgal mats on coastal ecosystems. Habitats such as open macrotidal sandy beaches should therefore be taken into account in the development of indices and regulation of eutrophication by macroalgal mats. Finally, our conclusions raise questions regarding the functioning of such dynamic systems under eutrophication stress.

Acknowledgements. The authors thank the great group of students, technicians, engineers and researchers who helped in sampling and hand-sieving a huge amount of sand; in sorting hundreds of samples; and who braved the (in)famous Breton weather conditions. Foremost, we thank S. Castay, C. Jouan, M. Maguer, V. Le Garrec, S. Laurand, G. Schaal and D. Zeppilli. We also thank S. Ballu (CEVA) for providing us with the Ulva mat dataset and precious information about green tide processes in Brittany. O. Defeo and 3 anonymous reviewers provided helpful comments on an earlier version of this manuscript. This work was carried out as part of the PhD dissertation of N.Q. for Université de Bretagne Occidentale and Åbo Akademi University. This study was supported by the national interdisciplinary Ecosphère Continentale et Côtière EC2CO-INSU MAVERIQ, the Région Bretagne and the Université de Bretagne Occidentale. E.B. and M.C.N. are supported by the Åbo Akademi University Endowment and O.G. by the Centre National de la Recherche Scientifique (CNRS) research grant. 


\section{LITERATURE CITED}

Addicott JF, Aho JM, Antolin MF, Padilla DK, Richardson JS, Soluk DA (1987) Ecological neighborhoods: scaling environmental patterns. Oikos 49:340-346

Allaby M (2010) A dictionary of ecology, 4th edn. Oxford University Press, Oxford

> Anderson MJ, Gribble NA (1998) Partitioning the variation among spatial, temporal and environmental components in a multivariate data-set. Aust J Ecol 23:158-167

Ansell AD, Lagardère F (1980) Observations on the biology of Donax trunculus and Donax vittatus at lle d'Oléron (French Atlantic Coast). Mar Biol 57:287-300

Augris C, Ménesguen A, Hamon D, Blanchet A and others (2005) Atlas thématique de l'environnement marin de la baie de Douarnenez (Finistère). Ed. Ifremer; Plouzané

Beyst B, Cattrijsse A, Mees J (1999) Feeding ecology of juvenile flat fishes of the surf zone of a sandy beach. J Fish Biol 55:1171-1186

> Blanchet FG, Legendre P, Borcard D (2008) Forward selection of explanatory variables. Ecology 89:2623-2632

Blott SJ, Pye K (2001) GRADISTAT: a grain size distribution and statistics package for the analysis of unconsolidated sediments. Earth Surf Process Landf 26:1237-1248

Bolam SG, Fernandes TF, Read P, Raffaelli D (2000) Effects of macroalgal mats on intertidal sandflats: an experimental study. J Exp Mar Biol Ecol 249:123-137

Bombelli V, Lenzi M (1996) Italy. The Orbetello lagoon and the Tuscany coast. Ecol Stud 123:331-337

> Borcard D, Legendre P (1994) Environmental control and spatial structure in ecological communities: an example using oribatid mites (Acari, Oribatei). Environ Ecol Stat 1:37-61

Botsford LW, Castilla JC, Peterson CH (1997) The management of fisheries and marine ecosystems. Science 277: 509-515

Brown AC, McLachlan A (2002) Sandy shore ecosystems and the threats facing them: some predictions for the year 2025. Environ Conserv 29:62-77

Carcedo C, Fiori S, Bremec C (2014) Macrobenthic surf zone communities of temperate sandy beaches: spatial and temporal patterns. Mar Ecol (Berl) 35:1-11

Carriço R, Zeppilli D, Quillien N, Grall J (2013) Can meiofauna be a good biological indicator of the impacts of eutrophication caused by green macroalgal blooms? An aod-les cahiers naturalistes de l'Observatoire marin 2: $9-16$

CGDD (Commissariat Général an Developpement Durable) (2014) Les proliférations d'algues sur les côtes métropolitaines. Le point sur, no. 180. Commissariat général an developpement durable. Service de l'observation et des statistiques. www.developpement-durable.gouv.fr/IMG/ pdf/LPS180.pdf (accessed 24 Apr 2014)

Charlier RH, Morand P, Finkl CW, Thys A (2007) Green tides on the Brittany coasts. Environ Res Eng Manage 41: $52-59$

Cloern JE (2001) Our evolving conceptual model of the coastal eutrophication problem. Mar Ecol Prog Ser 210: 223-253

Colombini I, Aloia A, Fallaci M, Pezzoli G, Chelazzi L (2000) Temporal and spatial use of stranded wrack by the macrofauna of a tropical sandy beach. Mar Biol 136: 531-541

Connell JH (1978) Diversity in tropical rain forests and coral reefs. Science 199:1302-1310
Corzo A, van Bergeijk SA, Garcia-Robledo E (2009) Effects of green macroalgal blooms on intertidal sediments: net metabolism and carbon and nitrogen contents. Mar Ecol Prog Ser 380:81-93

Da Silva PSR, das Neves LP, Bemvenuti CE (2008) Temporal variation of sandy beach macrofauna at two sites with distinct environmental conditions on Cassino Beach, extreme southern Brazil. Braz J Oceanogr 56:257-270

de Juan S, Hewitt J (2014) Spatial and temporal variability in species richness in a temperate intertidal community. Ecography 37:183-190

Defeo O, de Alava A (1995) Effects of human activities on long-term trends in sandy beach populations: the wedge clam Donax hanleyanus in Uruguay. Mar Ecol Prog Ser 123:73-82

Defeo O, McLachlan A (2005) Patterns, processes and regulatory mechanisms in sandy beach macrofauna: a multiscale analysis. Mar Ecol Prog Ser 295:1-20

> Defeo O, McLachlan A, Schoeman DS, Schlacher TA and others (2009) Threats to sandy beach ecosystems: a review. Estuar Coast Shelf Sci 81:1-12

> Degraer S, Mouton I, De Neve L, Vincx M (1999) Community structure and intertidal zonation of the macrobenthos on a macrotidal, ultra-dissipative sandy beach: summer-winter comparison. Estuaries 22:742-752

Dray S (with contributions of Legendre P and Blanchet G) (2013) packfor: forward selection with permutation (Canoco p.46). R package version 0.0-8/r109, available at http://R-Forge.R-project.org/projects/sedar/

Dray S, Legendre P, Peres-Neto PS (2006) Spatial modelling: a comprehensive framework for principal coordinate analysis of neighbour matrices (PCNM). Ecol Model 196: 483-493

Dray S, Pélissier R, Couteron P, Fortin MJ and others (2012) Community ecology in the age of multivariate multiscale spatial analysis. Ecol Monogr 82:257-275

- Dugan JE, Hubbard DM, McCrary MD, Pierson MO (2003) The response of macrofauna communities and shorebirds to macrophyte wrack subsidies on exposed sandy beaches of southern California. Estuar Coast Shelf Sci 58: $25-40$

> Dugan JE, Jaramillo E, Hubbard DM, Contreras H (2004) Competitive interactions in macroinfaunal animals of exposed sandy beaches. Oecologia 139:630-640

Dussauze M, Ménesguen A (2008) Simulation de l'effet sur l'eutrophisation côtière bretonne de 3 scénarios de réduction des teneurs en nitrate et phosphate de chaque bassin versant breton et de la Loire. Ifremer RST DYNECO/EB/08-08/AM

- Everett RA (1994) Macroalgae in soft-sediment communities: effects on benthic faunal assemblages. J Exp Mar Biol Ecol 175:253-274

$>$ Franz DR, Friedman I (2002) Effects of a macroalgal mat (Ulva lactuca) on estuarine sand flat copepods: an experimental study. J Exp Mar Biol Ecol 271:209-226

Glémarec M (1969) Les peuplements benthiques du plateau continental Nord-Gascogne. PhD dissertation, Université de Bretagne Occidentale

Gonçalves C, Anasta PM, Pardal MA (2009) Sandy beach macrofaunal communities on the western coast of Portugal-Is there a steady structure under similar exposed conditions? Estuar Coast Shelf Sci 81:555-568

> Gotelli NJ, Colwell RK (2001) Quantifying biodiversity: procedures and pitfalls in the measurement and comparison of species richness. Ecol Lett 4:379-391 
Grall J, Chauvaud L (2002) Marine eutrophication and benthos: the need for new approaches and concepts. Glob Change Biol 8:813-830

Grall J, Le Loc'h F, Guyonnet B, Riera P (2006) Community structure and food web based on stable isotopes $\left(\delta^{15} \mathrm{~N}\right.$ and $\delta^{13} \mathrm{C}$ ) analysis of a North Eastern Atlantic maerl bed. J Exp Mar Biol Ecol 338:1-15

Gray JS, Elliott M (2009) Ecology of marine sediments. From science to management, 2nd edn. Oxford University Press, Oxford

Guillou J (1982) Variabilité des populations de Donax trunculus et Donax vittatus en Baie de Douarnenez. Neth J Sea Res 16:88-95

Hénaff A (1998) Morphologie dynamique et budget sédimentaire des estrans meubles de la façade occidentale de la Presqu'île de Crozon, de l'anse de Combrit et de l'anse du Pouldu. PhD dissertation, Université de Bretagne Occidentale, Brest

Hewitt JE, Thrush SE, Cummings VJ (2001) Assessing environmental impacts: effects of spatial and temporal variability at likely impact scales. Ecol Appl 11:1502-1516

Hull SC (1987) Macroalgal mats and species abundance: a field experiment. Estuar Coast Shelf Sci 25:519-532

James RJ, Fairweather PG (1996) Spatial variation of intertidal macrofauna on a sandy ocean beach in Australia. Estuar Coast Shelf Sci 43:81-107

Jeffrey DW, Madden B, Rafferty B, Dwyer R, Wilson J, Arnott N (1992) Dublin Bay water quality management plan. Technical report 7. Algal growths and foreshore quality. Environmental Research Unit, Dublin

Jost L (2006) Entropy and diversity. Oikos 113:363-375

Kindt R, Coe R (2005) Tree diversity analysis. A manual and software for common statistical methods for ecological and biodiversity studies. World Agroforestry Centre (ICRAF), Nairobi

> Lastra M, de La Huz R, Sánchez-Mata AG, Rodil IF, Aerts K, Beloso S, López J (2006) Ecology of exposed sandy beaches in northern Spain: environmental factors controlling macrofauna communities. J Sea Res 55:128-140

Leber KM (1982) Seasonality of macroinvertebrates on a temperate, high wave, energy sandy beach. Bull Mar Sci 32:86-98

> Legendre P, Anderson MJ (1999) Distance-based redundancy analysis: testing multispecies responses in multifactorial ecological experiments. Ecol Monogr 69:1-24

> Legendre P, Gallagher E (2001) Ecologically meaningful transformations for ordination of species data. Oecologia 129:271-280

Legendre P, Gauthier O (2014) Statistical methods for temporal and space-time analysis of community composition data. Proc R Soc Lond B Biol Sci 281:20132728

Legendre P, Legendre L (2012) Numerical ecology, 3rd edn. Elsevier Science, Amsterdam

Legendre P, De Càceres M (2013) Beta diversity as the variance of community data: dissimilarity coefficients and partitioning. Ecol Lett 16:951-963

Legendre P, Borcard D, Blanchet G, Dray S (2013) PCNM: MEM spatial eigenfunction and principal coordinate analyses. $\mathrm{R}$ package version 2.1-2/r109. R Foundation for Statistical Computing, Vienna. Available at http://RForge.R-project.org/projects/sedar/

Lercari D, Defeo O (1999) Effects of freshwater discharge in sandy beach populations: the mole crab Emerita brasiliensis in Uruguay. Estuar Coast Shelf Sci 49: 457-468
McLachlan A (1983) Sandy beach ecology - a review. In: McLachlan A, Erasmus T (eds) Sandy beaches as ecosystems. Dr W. Junk Publishers, The Hague, p 321-380

McLachlan A, Brown AC (2006) The ecology of sandy shores. Academic Press, Burlington, MA

McLachlan A, Dorvlo A (2005) Global patterns in sandy beach macrobenthic communities. J Coast Res 21: $674-687$

Ménesguen A, Piriou JY (1995) Nitrogen loadings and macroalgal (Ulva sp.) mass accumulation in Brittany (France). Ophelia 42:227-237

- Miller DC, Geider RJ, MacIntyre HL (1996) Microphytobenthos: the ecological role of the 'secret garden' of unvegetated, shallow-water marine habitats. II. Role in sediment stability and shallow-water food webs. Estuaries 19: 202-212

> Morrisey DJ, Underwood AJ, Howitt L, Stark JS (1992) Temporal variation in soft-sediment benthos. J Exp Mar Biol Ecol 164:233-245

Nel R, Campbell E, Harris L, Hauser L and others (2014) The status of sandy beach science: past trends, progress, and possible futures. Estuar Coast Shelf Sci 150:1-10

> Nordström M, Booth DM (2007) Drift algae reduce foraging efficiency of juvenile flatfish. J Sea Res 58:335-341

> Norkko A, Bonsdorff E (1996) Rapid zoobenthic community responses to accumulations of drifting algae. Mar Ecol Prog Ser 131:143-157

Oksanen J, Blanchet GF, Kindt R, Legendre P, O'Hara RB (2011) vegan: community ecology package. R Foundation for Statistical Computing, Vienna, available at www. cran.r-project.org/web/packages/vegan/index.html (accessed 12 May 2014)

> Ouisse V, Riera P, Migné A, Leroux C, Davoult D (2011) Freshwater seepages and ephemeral macroalgae proliferation in an intertidal bay: I. Effect on benthic community structure and food web. Estuar Coast Shelf Sci 91: 272-281

Pearson TH, Rosenberg R (1978) Macrobenthic successions in relation to organic enrichment and pollution of the marine environment. Oceanogr Mar Biol Annu Rev 16: 229-311

R Development Core Team (2013) R: a language and environment for statistical computing. R Foundation for Statistical Computing, Vienna, available at www.Rproject.org

Rabaut M, Audfroid Calderon M, Van De Moortel L, Van Dalfsen J, Vincx M, Degraer S, Desroy N (2013) The role of structuring benthos for juvenile flatfish. J Sea Res 84: 70-76

Raffaelli DG, Raven JA, Poole LJ (1998) Ecological impact of green macroalgal blooms. Oceanogr Mar Biol Annu Rev 36:97-125

> Resh VH, Rosenberg DM (1989) Spatial-temporal variability and the study of aquatic insects. Can Entomol 121: 941-963

> Rodil IF, Lastra M, Sánchez-Mata AG (2006) Community structure and intertidal zonation of the macroinfauna in intermediate sandy beaches in temperate latitudes: North coast of Spain. Estuar Coast Shelf Sci 67:267-279

> Rundle HD, Jackson DA (1996) Spatial and temporal variation in littoral-zone fish communities : a new statistical approach. Can J Fish Aquat Sci 53:2167-2176

Schlacher TA, Thompson L (2013) Spatial structure on ocean-exposed sandy beaches: faunal zonation metrics and their variability. Mar Ecol Prog Ser 478:43-55 
Schlacher TA, Dugan J, Schoeman DS, Lastra M and others (2007) Sandy beaches at the brink. Divers Distrib 13: 556-560

Schlacher TA, Schoeman DS, Dugan J, Lastra M, Jones A, Scapini F, McLachlan A (2008) Sandy beach ecosystems: key features, sampling issues, management challenges and climate change impacts. Mar Ecol (Berl) 29:70-90

Schoeman DS, Richardson AJ (2002) Investigating biotic and abiotic factors affecting recruitment of an intertidal clam on an exposed sandy beach using a generalized additive model. J Exp Mar Biol Ecol 276:67-81

Short AD (1996) The role of wave height, slope, tide range and embaymentisation in beach classification: a review. Rev Chil Hist Nat 69:589-604

Smart SM, Thompson K, Marrs RH, Le Duc MG, Maskell LC, Firbank LG (2006) Biotic homogenization and changes in species diversity across human-modified ecosystems. Proc R Soc Lond B Biol Sci 273:2659-2665

Soares AG, Schlacher TA, McLachlan A (1997) Carbon and nitrogen exchange between sandy beach clams (Donax serra) and kelp beds in the Benguela coastal upwelling region. Mar Biol 127:657-664

Speybroeck J, Alsteens L, Vincx M, Degraer S (2007) Understanding the life of a sandy beach polychaete of functional importance Scolelepis squamata (Polychaeta: Spionidae) on Belgian sandy beaches (northeastern Atlantic, North Sea). Estuar Coast Shelf Sci 74:109-118

Sundbäck K (1994) The response of shallow-water sediment communities to environmental changes. In: Krumbein E, Paterson DM, Stahl LJ (eds) Biostabilisation of sediments. Bibliotheks- und Informationssystem der Carl von

Editorial responsibility: Omar Defeo, Montevideo, Uruguay
Ossietzky Universität Oldenburg BIS-Verlag, Oldenburg, p $17-40$

> Thiel M, Watling L (1998) Effects of green algal mats on infaunal colonization of a New England mud flat-longlasting but highly localized effects. Hydrobiologia 375376:177-189

> Törnroos A, Bonsdorff E (2012) Developing the multitrait concept for functional diversity: lessons from a system rich in functions but poor in species. Ecol Appl 22: 2221-2236

Turner RK, Subak S, Adger WN (1996) Pressures, trends, and impacts in coastal zones: interactions between socioeconomic and natural systems. Environ Manage 20: 159-173

- Veiga P, Rubal M, Cacabelos E, Maldonado C, Sousa-Pinto I (2014) Spatial variability of macrobenthic zonation on exposed sandy beaches. J Sea Res 90:1-9

- Veloso VG, Cardoso RS (2001) The effect of morphodynamics on the spatial and temporal variation of the macrofauna of three sandy beaches on the Rio de Janeiro State, Brazil. J Mar Biol Assoc UK 81:369-375

- Weston D (1990) Quantitative examination of macrobenthic community changes along an organic enrichment gradient. Mar Ecol Prog Ser 61:233-244

> Ye N, Zhang X, Mao Y, Liang C and others (2011) 'Green tides' are overwhelming the coastline of our blue planet: taking the world's largest example. Ecol Res 26:477-485

> Ysebaert T, Herman PMJ (2002) Spatial and temporal variation in benthic macrofauna and relationships with environmental variables in an estuarine, intertidal soft-sediment environment. Mar Ecol Prog Ser 244:105-124

Submitted: June 19, 2014; Accepted: December 2, 2014 Proofs received from author(s): February 21, 2015 